Article

\title{
Platinum and Platinum Group Metal-Free Catalysts for Anion Exchange Membrane Fuel Cells
}

\author{
Van Men Truong ${ }^{1}$, Julian Richard Tolchard ${ }^{2}$, Jørgen Svendby ${ }^{3}$, Maidhily Manikandan ${ }^{3}$ (D), \\ Hamish A. Miller ${ }^{4}\left(\mathbb{D}\right.$, Svein Sunde ${ }^{3, *}$, Hsiharng Yang ${ }^{1, *} \mathbb{D}$, Dario R. Dekel ${ }^{5, * \mathbb{D}}$ and \\ Alejandro Oyarce Barnett ${ }^{2,6, *}$ \\ 1 Graduate Institute of Precision Engineering, National Chung Hsing University, Taichung 40227, Taiwan; \\ mentruong0101@gmail.com \\ 2 Sustainable Energy Department, SINTEF Industri, Postboks 4760 Torgarden, 7465 Trondheim, Norway; \\ JulianRichard.Tolchard@sintef.no \\ 3 Department of Materials Science and Engineering, Norwegian University of Science and Technology, \\ NO-7491 Trondheim, Norway; jorgen.svendby@ntnu.no (J.S.); maidhily.manikandan@ntnu.no (M.M.) \\ 4 Istituto di Chimica dei Composti Organometallici (CNR-ICCOM), via Madonna del Piano 10, \\ 50019 Sesto Fiorentino, Firenze, Italy; hamish.miller@iccom.cnr.it \\ 5 The Wolfson Department of Chemical Engineering and the Nancy \& Stephan Grand Technion Energy \\ Program (GTEP), Technion, Israel Institute of Technology, Haifa 3200003, Israel \\ 6 Department of Energy and Process Engineering, Norwegian University of Science and Technology, \\ NO-7491 Trondheim, Norway \\ * Correspondence: svein.sunde@ntnu.no (S.S.); hsiharng@dragon.nchu.edu.tw (H.Y.); \\ dario@technion.ac.il (D.R.D.); AlejandroOyarce.Barnett@sintef.no (A.O.B.)
}

Received: 23 December 2019; Accepted: 19 January 2020; Published: 27 January 2020

\begin{abstract}
The development of active hydrogen oxidation reaction (HOR) and oxygen reduction reaction (ORR) catalysts for use in anion exchange membrane fuel cells (AEMFCs), which are free from platinum group metals (PGMs), is expected to bring this technology one step closer to commercial applications. This paper reports our recent progress developing HOR Pt-free and PGM-free catalysts $\left(\mathrm{Pd} / \mathrm{CeO}_{2}\right.$ and $\mathrm{NiCo} / \mathrm{C}$, respectively), and ORR PGM-free $\mathrm{Co}_{3} \mathrm{O}_{4}$ for AEMFCs. The catalysts were prepared by different synthesis techniques and characterized by both physical-chemical and electrochemical methods. A hydrothermally synthesized $\mathrm{Co}_{3} \mathrm{O}_{4}+\mathrm{C}$ composite ORR catalyst used in combination with $\mathrm{Pt} / \mathrm{C}$ as HOR catalyst shows good $\mathrm{H}_{2} / \mathrm{O}_{2}$ AEMFC performance (peak power density of $\sim 388 \mathrm{~mW} \mathrm{~cm}^{-2}$ ), while the same catalyst coupled with our flame spray pyrolysis synthesised $\mathrm{Pd} / \mathrm{CeO}_{2}$ anode catalysts reaches peak power densities of $\sim 309 \mathrm{~mW} \mathrm{~cm}^{-2}$. Changing the anode to nanostructured $\mathrm{NiCo} / \mathrm{C}$ catalyst, the performance is significantly reduced. This study confirms previous conclusions, that is indeed possible to develop high performing AEMFCs free from $\mathrm{Pt}$; however, the challenge to achieve completely PGM-free AEMFCs still remains.
\end{abstract}

Keywords: non-Pt electrocatalyst; non-PGM electrocatalyst; hydrogen oxidation reaction; oxygen reduction reaction; alkaline fuel cell

\section{Introduction}

Fuel cells are excellent energy convertors due to their advantages of high efficiency and high energy density, and have the potential to provide continuous zero-emission power. Among the different alternatives, anion exchange membrane fuel cells (AEMFCs) have been identified as a promising fuel cell technology, due to their potential advantages over the mature proton exchange membrane fuel cells $[1,2]$, which include the possibility of using non-noble metals as electrode catalysts due to the faster oxygen reduction reaction (ORR) kinetics in alkaline media [3,4]. A wide variety of catalysts 
may be used as ORR catalysts in AEMFC cathodes [5,6]. Among the non-precious metal catalysts for the cathode, $\mathrm{Ag}$ ( or $\mathrm{Ag} / \mathrm{C}$ ) is the most widely used catalyst for AEMFCs [7,8]. However, Co-based catalysts in the form of $\mathrm{Co}_{3} \mathrm{O}_{4}$, have also been recognized as potential ORR catalytic materials due to their low cost, good electrical conductivity, and stability in alkaline media [9-11]. For instance, $\mathrm{Xu}$ et al. [12] prepared carbon-supported $\mathrm{Co}_{3} \mathrm{O}_{4}$ electrocatalysts with nano-rod and spherical structures via a solvent-mediated morphological control route, showing only slightly lower ORR catalytic activity than that measured with the noble Pd catalyst in the high potential region. Wang et al. [13] synthesized $\mathrm{Co}_{3} \mathrm{O}_{4}$ clad with graphene oxide $\left(\mathrm{Co}_{3} \mathrm{O}_{4} @ \mathrm{GO}\right)$ by an ultrasonic method, which showed potentially good characteristics as a low-cost catalyst for ORR in AEMFCs. Liang et al. [14] reported that the catalytic behavior of $\mathrm{Co}_{3} \mathrm{O}_{4}$ grown on reduced graphene oxide (RGO) exhibits good activity towards ORR in alkaline electrolyte, close to that of $\mathrm{Pt} / \mathrm{C}$. These ex-operando results suggest that $\mathrm{Co}_{3} \mathrm{O}_{4}$ is a promising platinum group metal (PGM)-free electrocatalyst for ORR in AEMFCs. However, limited work has been reported on the performance of $\mathrm{Co}_{3} \mathrm{O}_{4}$-based ORR catalysts as real AEMFC cathodes $[9,15,16]$.

Although the alkaline environment in AEMFCs potentially allows the use of Pt-free catalysts for ORR, the hydrogen oxidation reaction (HOR) kinetics in alkaline media are considerably more sluggish than for acidic media [10]. The HOR has several challenges in the alkaline medium [11]. A comprehensive review summarizing the development efforts over the past decades on HOR catalysts in alkaline medium was recently reported [17]. In this regard, Pd-based electrocatalysts have emerged as one of the few options for Pt-free AEMFCs $[18,19]$. A new class of Pd-based materials that exploit mixed carbon and cerium oxide supports has been reported to have excellent performance as anode catalysts in AEMFCs, with reported power densities of $0.5-1 \mathrm{~W} \mathrm{~cm}^{-2}[20,21]$. In particular, the addition of $\mathrm{CeO}_{2}$ to Vulcan XC-72 carbon with a 50:50 weight ratio to support Pd nanoparticles was reported to yield a 5-fold improvement in anode performance when compared to Pd supported on carbon catalyst (without ceria) under the same fuel cell operating conditions. Miller et al. [18] posit that the presence of intimate contact between $\mathrm{CeO}_{2}$ and $\mathrm{Pd}$ enhances the $\mathrm{OH}^{-}$transfer from the anion-conducting regions in the anode electrode to the metal surface where the HOR takes place.

For PGM-free fuel cells, Ni-based electrocatalysts seem like a reasonable catalyst choice [21,22]. Various studies on Ni-based materials (Raney $\mathrm{Ni}, \mathrm{Ni}-\mathrm{Cr}$, Ni-Ti, etc.) have found them to be suitable as anode catalysts when the electrolyte is liquid $\mathrm{KOH}$. However, only limited work has been devoted to the development of Ni-based HOR catalysts for AEMFCs, where only a solid polymer electrolyte is present. The first fully PGM-free AEMFC test was demonstrated by Lu et al. [23] using a chromium doped Ni anode and $\mathrm{Ag}$ cathode. A maximum power density of $50 \mathrm{~mW} \mathrm{~cm}{ }^{-2}$ at $60^{\circ} \mathrm{C}$ was achieved without any degradation over $100 \mathrm{~h}$. Another study by $\mathrm{Hu}$ et al. [24] showed a Ni-W anode and Co-based cathode for $\mathrm{H}_{2} / \mathrm{O}_{2}$ and $\mathrm{H}_{2}$ /air AEMFCs, reaching peak power densities of around $40 \mathrm{mWcm}^{-2}$ and $27 \mathrm{mWcm}^{-2}$ respectively, demonstrating, for the first time, the potential of using PGM-free catalysts for AEMFCs. More recently, excellent performance has been demonstrated using $\mathrm{NiMo} / \mathrm{C}$ [25] and $\mathrm{NiCu} / \mathrm{C}$ [26] as anode catalyst, using the PGM Pd/C as cathode catalyst, showing AEMFC peak power densities of $120 \mathrm{~mW} \mathrm{~cm}^{-2}$ and $150 \mathrm{~mW} \mathrm{~cm}{ }^{-2}$, respectively.

The present study deals with the development of the next generation of materials focusing on affordable and abundant catalyst materials for AEMFCs. In particular, three catalysts for the anodic HOR are compared, including: (i) The state-of-the-art $10 \mathrm{wt} \% \mathrm{Pd} / \mathrm{C}-\mathrm{CeO}_{2}$ catalyst [18], (ii) a compositionally equivalent $10 \mathrm{wt} \% \mathrm{Pd} / \mathrm{CeO}_{2}+\mathrm{C}$ catalyst in which a $\mathrm{Pd}-\mathrm{CeO}_{2}$ nanocomposite is produced through a one-pot flame spray pyrolysis (FSP) synthesis before mixing with Vulcan XC-72, here denoted as "FSP Pd/CeO $\mathrm{Cl}_{2}$ ", and (iii) a nanostructured $50 \mathrm{wt} \% \mathrm{Ni}_{3} \mathrm{Co}$ alloy supported on Vulcan XC-72 (NiCo/C). The AEMFC cathode catalyst consists of $\mathrm{Co}_{3} \mathrm{O}_{4}$ prepared by hydrothermal synthesis and later mixed with Vulcan XC-72 (" $\left.\mathrm{Co}_{3} \mathrm{O}_{4}+\mathrm{C}^{\prime \prime}\right)$. The synthesized Pt-free catalysts were comprehensively characterized for their physicochemical properties using X-ray diffraction (XRD), transmission electron microscopy (TEM), and X-ray photoelectron spectroscopy (XPS) techniques. The paper focuses on the initial catalytic performance and kinetics of these catalysts towards HOR or ORR through conventional wet electrochemical methods, as well as their performance when 
integrated into AEMFC single cells using commercially available gas diffusion layers (GDLs), anion exchange membranes (AEMs) and ionomer. Here, the catalysts are evaluated for their beginning-of-life performance in $\mathrm{H}_{2} / \mathrm{O}_{2}$ AEMFCs single cells.

\section{Results and Discussion}

\subsection{Physical Characterization}

\subsubsection{Physical Characterization of the $\mathrm{Co}_{3} \mathrm{O}_{4}$ ORR Catalyst}

Figure 1c shows the fitted XRD for the cobalt oxide product phase after heat treatment at $250{ }^{\circ} \mathrm{C}$ in air, with fitted diffraction data for the cobalt carbonate precursor presented in the Supplementary Information (Figure S1). It is seen that the cobalt carbonate precursor forms as agglomerated platelets of an individual size of less than $10 \mu \mathrm{m}$ (Figure 1a). Ball milling breaks up these agglomerates effectively, and it is confirmed that following heat-treatment, a product phase is obtained which comprises FCC nanoparticles in the order of 10-20 nm in size, arranged in highly anisotropic "platelets" which are up to micron-sized in two dimensions, but are only 1-3 particles in thickness (Figure 1b,d). The powder XRD pattern (Figure 1c) confirms that the sample is a single spinel structured $\mathrm{Co}_{3} \mathrm{O}_{4}$, with a fitted unit cell parameter of $\mathrm{a}=8.0846(8) \AA$ [27]. A volume-weighted crystallite size of 13.5(3) nm was calculated via whole powder pattern fitting of the peak profiles.
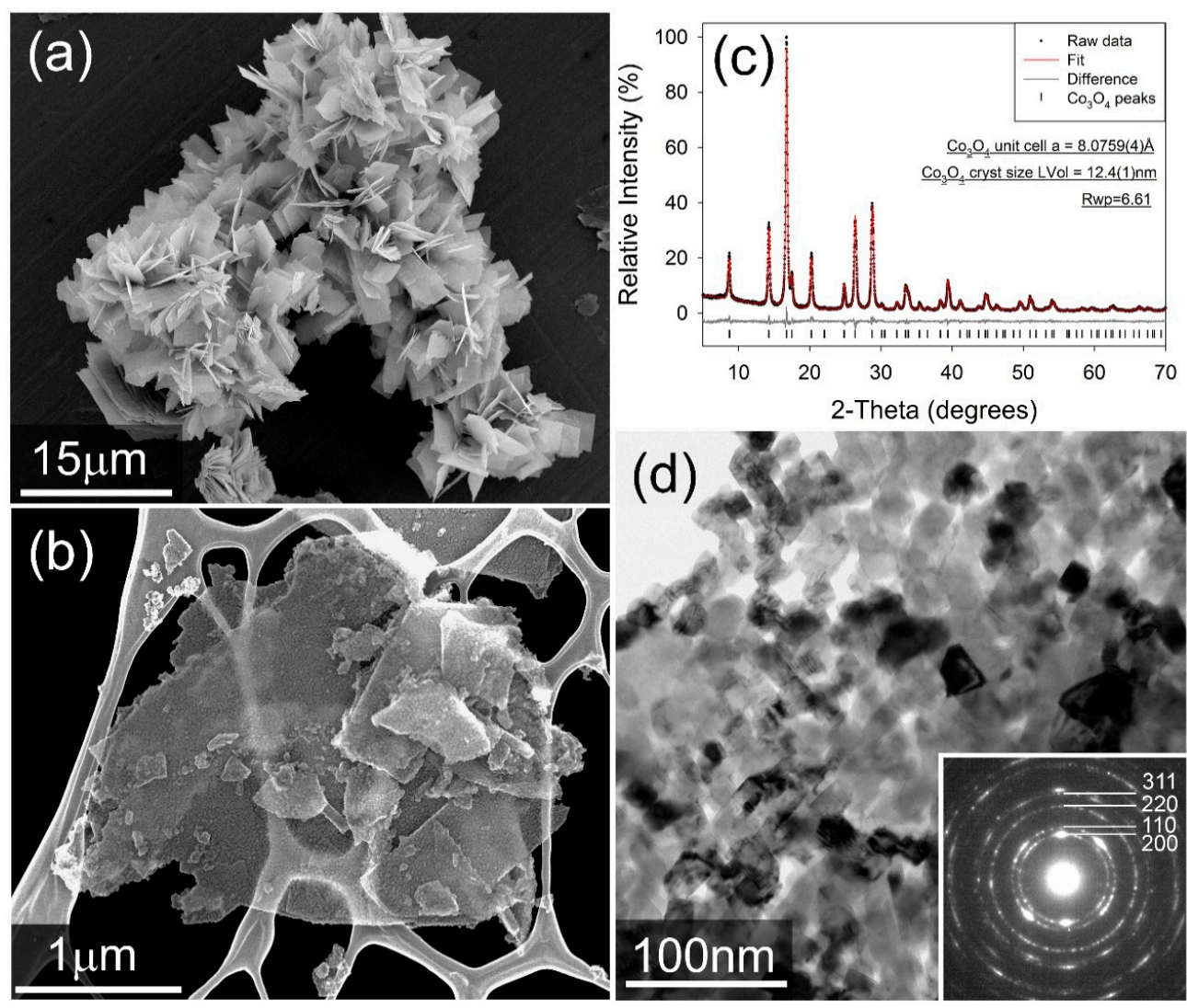

Figure 1. (a) Secondary electron image of as-made $\mathrm{Co}_{2}\left(\mathrm{CO}_{3}\right) \mathrm{OH}_{2}$. (b) secondary electron image of the milled $\mathrm{Co}_{3} \mathrm{O}_{4}$ catalyst. We note that the sample was mounted on a Lacey Carbon TEM grid for imaging. (c) Fitted X-ray diffractogram for the $\mathrm{Co}_{3} \mathrm{O}_{4}$ catalyst. Data were collected in capillary transmission mode using a Mo-K $\mathrm{K}_{\alpha}$ source and modelled using a Rietveld-type approach. (d) bright-field TEM image of $\mathrm{Co}_{3} \mathrm{O}_{4}$ catalyst particles. Inset: Selected-area electron diffraction pattern, showing rings consistent with an FCC lattice. 


\subsubsection{Physical Characterization of the HOR Catalysts}

Figure $2 b-g$ display the annular dark field STEM images and associate chemical maps for the $10 \mathrm{wt} \% \mathrm{Pd} / \mathrm{C}-\mathrm{CeO}_{2}$ catalyst. The catalyst is a mixed composite of crystalline Pd particles of size $<10 \mathrm{~nm}, \mathrm{CeO}_{2}$ agglomerates in the 10-40 nm size range, and carbon particles of around $50-70 \mathrm{~nm}$. The $\mathrm{CeO}_{2}$ particles and $\mathrm{Pd}$ particles appear to be quite well distributed on the carbon support but are not strongly associated with each other.
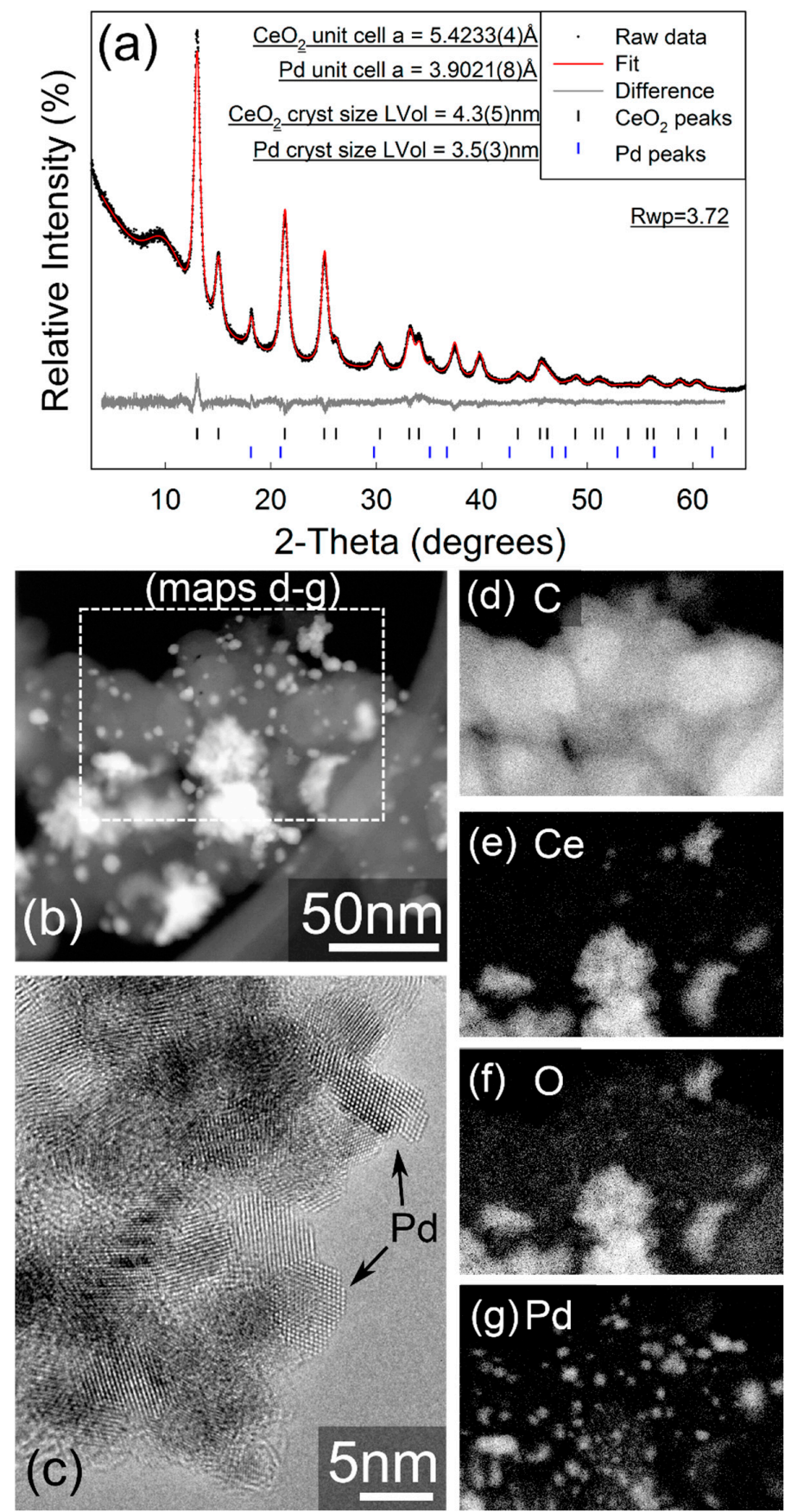

Figure 2. (a) Fitted X-ray powder diffractogram for $\mathrm{Pd} / \mathrm{C}-\mathrm{CeO}_{2}$. Data were collected in capillary transmission mode using a Mo- $\mathrm{K}_{\alpha}$ source and modelled using a Rietveld-type approach. The "amorphous bump" at approx. $9^{\circ} 2 \theta$ is due to the Kapton capillary material. (b) Annular dark-field STEM image, (c) high-resolution TEM image showing crystalline Pd particles, (d-g) elemental EDX images acquired within the area indicated in (b). Gamma adjustments were applied in $(\mathbf{b}, \mathbf{d}-\mathbf{g})$. 
In contrast, the STEM imaging and EELS element mapping for the as-synthesized $\mathrm{FSP} \mathrm{Pd} / \mathrm{CeO}_{2}$ sample (Figure $3 \mathrm{~b}-\mathrm{e}$ ) show an extremely even distribution of $\mathrm{Pd}$ and $\mathrm{CeO}_{2}$, which is a consequence of the single step FSP synthesis. The FSP sample also demonstrates regions of Pd enrichment which show no apparent crystallinity and are sufficiently small $(\sim 1 \mathrm{~nm})$ that it is unclear whether these can even be considered as formal particles, and the $\mathrm{Pd}$ in a separate phase to the $\mathrm{CeO}_{2}$. The $10 \mathrm{wt} \%$ $\mathrm{Pd} / \mathrm{C}-\mathrm{CeO}_{2}$ catalyst has previously been characterized by XRD, XAS and other techniques [18-21]. However, the XRD data for both the $10 \mathrm{wt} \% \mathrm{Pd} / \mathrm{C}-\mathrm{CeO}_{2}$ and as-synthesizes FSP $\mathrm{Pd} / \mathrm{CeO}_{2}$ may be compared in Figures 2a and 3a, respectively. For both samples nanocrystalline $\mathrm{CeO}_{2}$ is observed, with calculated crystallite sizes of 4.35(5) $\mathrm{nm}$ and 3.08(3) nm calculated for the $10 \mathrm{wt} \% \mathrm{Pd} / \mathrm{C}-\mathrm{CeO}_{2}$ and FSP $\mathrm{Pd} / \mathrm{CeO}_{2}$ samples, respectively. Similar unit cell parameters of $\mathrm{a}=5.4230(4) \AA$ and $\mathrm{a}=5.4263(4) \AA$ are obtained for the $\mathrm{CeO}_{2}$ phase in the two respective samples. For the $10 \mathrm{wt} \% \mathrm{Pd} / \mathrm{C}-\mathrm{CeO}_{2}$ sample, relatively sharp diffraction lines due to crystalline $\mathrm{Pd}$ are also observed, which suggests that a portion of the $\mathrm{Pd}$ in this sample has a much larger particle/crystallite size than that observed by electron microscopy. No evidence of a crystalline Pd-containing phase is observed in the diffraction data for the $\mathrm{FSP} \mathrm{Pd} / \mathrm{CeO}_{2}$ sample.
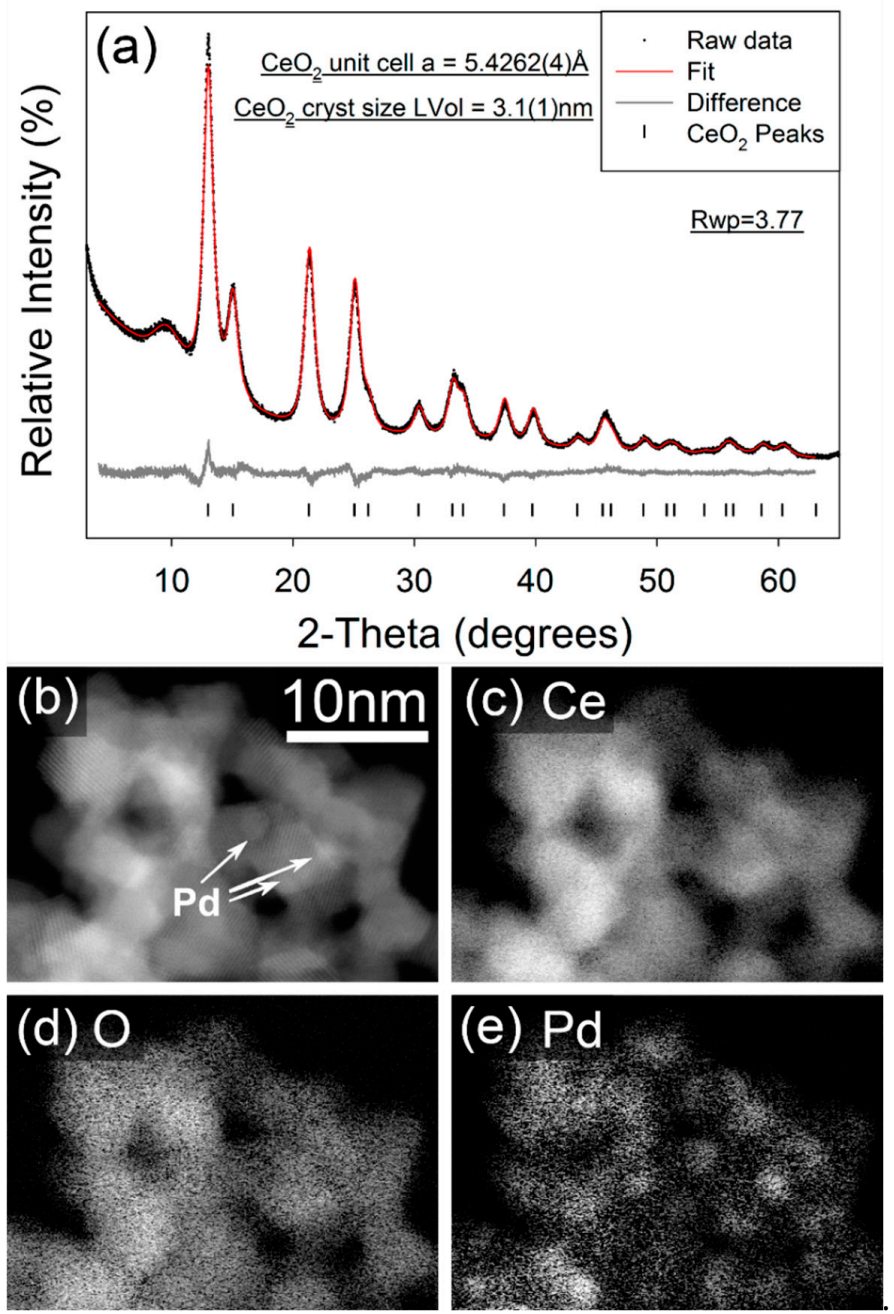

Figure 3. (a) Fitted X-ray powder diffractograms for FSP synthesized FSP $\mathrm{Pd} / \mathrm{CeO}_{2}$. Data were collected in capillary transmission mode using a Mo- $\mathrm{K}_{\alpha}$ source and modelled using a Rietveld-type approach. The "amorphous bump" at $\sim 9^{\circ}$ 2-Theta is due to the Kapton capillary material, (b) STEM image, and (c-e) elemental EELS maps from FSP $\mathrm{Pd} / \mathrm{CeO}_{2}$. 
XPS data are presented in Figure $4 a-d$, with a summary of the $\operatorname{Pd} 3 d_{5 / 2}$ binding energies presented in Table 1. Both samples show Ce(3d) spectra with binding energies characteristic of both Ce(IV) and $\mathrm{Ce}$ (III) species. Based on relative areas a ratio of approximately 70:30 is determined. However, the fitting and quantification of $\mathrm{CeO}_{2}$, especially $\mathrm{CeO}_{2}$ nanoparticles, are known to be challenging and unreliable, due to the heavy peak overlap in the spectra and surface stabilization of Ce(III). This causes a general over-estimation of the $\mathrm{Ce}$ (III) content in $\mathrm{CeO}_{2}$ nanomaterials, and can easily lead to misinterpretation of results [28,29]. Consequently, only a limited conclusion is drawn: That there are no significant differences between the Ce spectra of the $10 \mathrm{wt} \% \mathrm{Pd} / \mathrm{C}-\mathrm{CeO}_{2}$ and $\mathrm{FSP} \mathrm{Pd} / \mathrm{CeO}_{2}$ samples. In contrast, the Pd XPS spectra show marked differences between the samples. The $10 \mathrm{wt} \% \mathrm{Pd} / \mathrm{C}-\mathrm{CeO}_{2}$ Palladium spectrum in Figure 4 a can be deconvoluted in terms of three $P d 3 d_{5 / 2} / 3 d_{3 / 2}$ doublets, while the FSP Pd/CeO $/ \mathrm{Cample}_{2}$ in Figure $4 \mathrm{~b}$ is predominantly a single doublet, with a small fraction of a second species present.
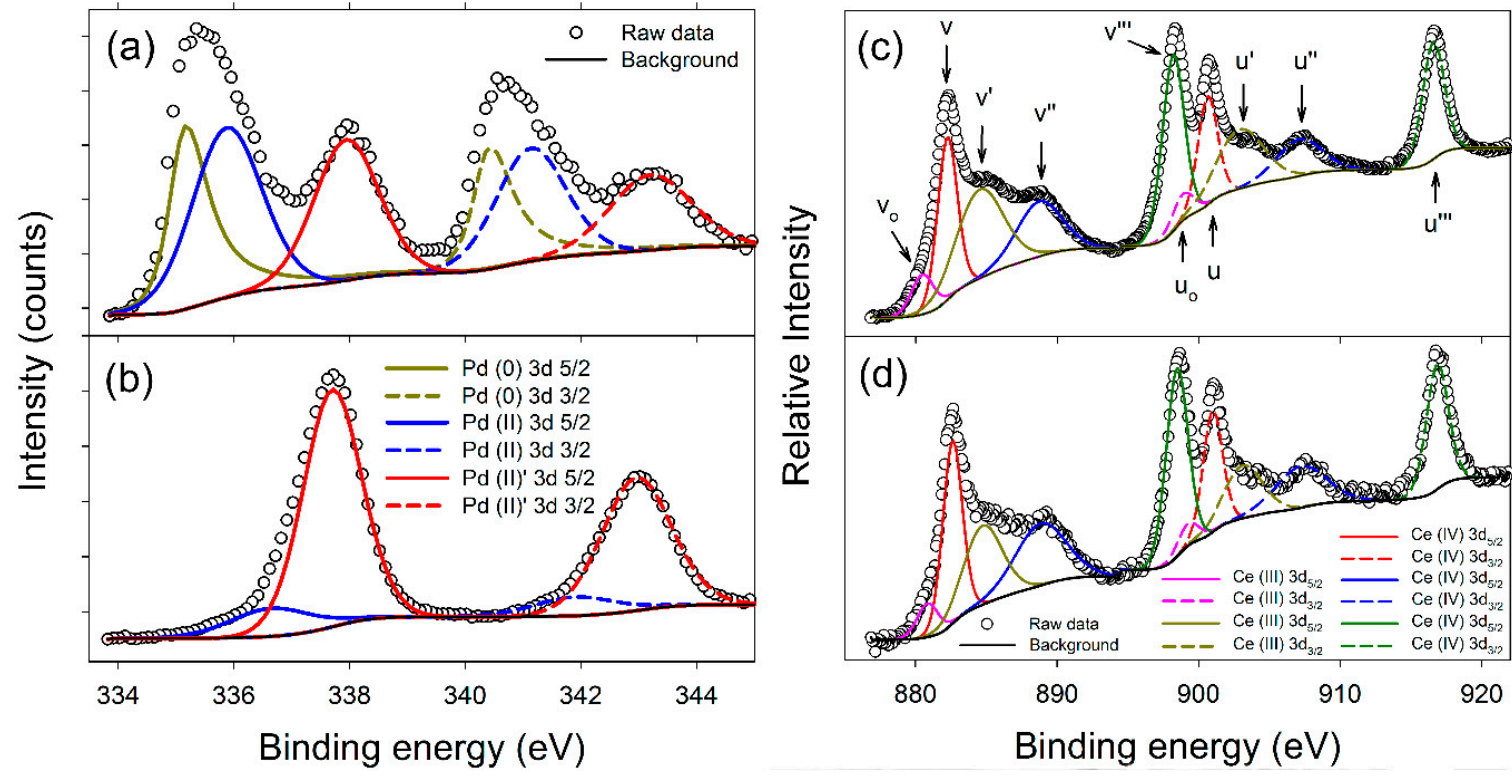

Figure 4. XPS data for Pd for (a) $\mathrm{Pd} / \mathrm{C}-\mathrm{CeO}_{2}$, and (b) FSP Pd/CeO 2 . Lines marked $\mathrm{Pd}(0), \mathrm{Pd}(\mathrm{II})$ and $\mathrm{Pd}(\mathrm{II})$ are assigned respectively to metallic $\mathrm{Pd}$, sub-stoichiometric $\mathrm{PdO}$ and super-stoichiometric PdO. XPS data for Ce for (c) $\mathrm{Pd} / \mathrm{C}-\mathrm{CeO}_{2}$, and (d) FSP Pd/CeO . To aid comparison with previous work, the commonly used nomenclature of Burroughs et al. [30] was adopted in (c).

Table 1. Normalized $\mathrm{Pd} 3 \mathrm{~d}_{5 / 2}$ binding energies for the $\mathrm{Pd} / \mathrm{C}-\mathrm{CeO}_{2}$ and $\mathrm{FSP} 18 \% \mathrm{Pd} / \mathrm{CeO}_{2}$ samples.

\begin{tabular}{cccc}
\hline $\mathbf{P d}$ & $\mathbf{1 0} \mathbf{w t} \mathbf{\%} \mathbf{P d} / \mathbf{C}-\mathbf{C e O}_{\mathbf{2}}$ & $\mathbf{F S P} \mathbf{1 8} \% \mathbf{P d} / \mathbf{C e O}_{\mathbf{2}}$ & Ref [31,32] \\
\hline $\mathrm{Pd}(0)$ & 335.2 & $\mathrm{~N} / \mathrm{A}$ & $335.1-335.4$ \\
$\mathrm{Pd}(\mathrm{II})$ & 335.9 & 336.7 & $336.7-336.8$ \\
$\mathrm{Pd}(\mathrm{II})$ & 337.9 & 337.7 & see main text \\
\hline
\end{tabular}

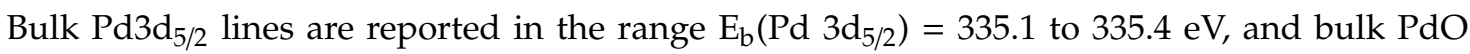

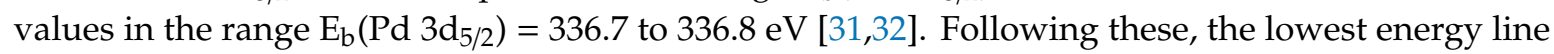
observed in the $10 \mathrm{wt} \% \mathrm{Pd} / \mathrm{C}-\mathrm{CeO}_{2}$ spectrum is assigned to metallic Pd, and the line at $\mathrm{E}_{\mathrm{b}}=335.9 \mathrm{eV}$ to a sub-stoichiometric $\mathrm{PdO}_{1-\mathrm{x}}$ species, due to the shift in binding energy (BE) relative to PdO. The FSP-synthesized FSP Pd/CeO $\mathrm{C}_{2}$ shows no evidence of metallic $\mathrm{Pd}$, and only a weak signal which can similarly be attributed to a PdO-type $\mathrm{Pd}(\mathrm{II})$ signal (Figure $4 \mathrm{~b}$ ). This peak is broad though, and likely also describes some sub-stoichiometric $\mathrm{PdO}_{1-\mathrm{x}}$. Both the $10 \mathrm{wt} \% \mathrm{Pd} / \mathrm{C}-\mathrm{CeO}_{2}$ and $\mathrm{FSP} \mathrm{Pd} / \mathrm{CeO}_{2}$ samples exhibit strong lines at a higher $\mathrm{BE}$ that can be attributed to a $\mathrm{PdO}$ type species, and at a similar energy to that for Pd(IV) $[33,34]$. This line is labelled Pd(II) so as to avoid confusion, as the composition $\mathrm{PdO}_{2}$ 
is not stable under the conditions of the sample preparation, and the presence of a formal $\mathrm{Pd}^{4+}$ bulk oxide cannot be concluded. Nevertheless, the high BE does indicate a high level of charge transfer from the $\mathrm{Pd}$. Several authors have reported $\mathrm{Pd} 3 \mathrm{~d}_{5 / 2}$ lines with similar binding energies for supported $\mathrm{Pd}$ catalysts $[35,36]$. Most ascribe the shift to a higher BE to an interaction between the catalyst and $\mathrm{CeO}_{2}$ support, though it is documented that for metallic systems a reduction in particle size at the extreme nano-scale can cause a shift to higher binding energies [37,38].

Figure 5 a shows the fitted $X$-ray diffraction pattern for the PGM-free NiCo/C catalyst after annealing at $500{ }^{\circ} \mathrm{C}$. The diffraction pattern for the sample, prior to annealing, is given in the Supplementary Information (Figure S2). The observed pattern after annealing can be fitted to a FCC unit cell with unit cell parameter $\mathrm{a}=3.5306(5) \AA$, which corresponds well to a composition of approximately $\mathrm{Ni}_{0.6} \mathrm{Co}_{0.4}[39]$. A broad region of unfitted intensity is also evident around the (100) reflection. The position of this correlates with that expected for the hexagonal crystal structure for Co or a Cobalt-rich Co-Ni, though the presence of no well-defined maxima suggests a high level of faulting or structural disorder in the hexagonal fraction. The cubic to hexagonal transformation, and concomitant formation of high stacking fault density is well known in the pure cobalt system [40]. It has also been reported that there is a strong correlation between particle size and the favored crystalline polymorph of $\mathrm{Co}$, with the cubic phase being stable below a particle diameter of $\sim 20 \mathrm{~nm}$ and a mixture of hexagonal and cubic phases being favored above that [41]. The NiCo catalyst in this study are spherical in morphology and are dispersed onto the carbon surface. The catalyst particles tend to agglomerate after annealing, resulting in an increased nanoparticle size from 7-10 nm range (pristine) to 15-20 nm (after annealing). The resulting particle size and size distribution of the catalyst after annealing may be seen in the bright and dark field images of $\mathrm{NiCo} / \mathrm{C}$ (Figure S3). Figure 5b,c further show the HAAD-STEM image, as well as the corresponding STEM-EDX elemental line scan and mapping. The characterization data confirm that the NiCo nanoparticles consist of an alloy of $\mathrm{Ni}$ and $\mathrm{Co}$, with the EDS line scan showing relatively homogeneous composition across the particle, with a slight Ni-enrichment suggested at the core. The measured particle composition is slightly more Ni-rich than that suggested by the unit cell parameter calculated from the XRD data. Also observed in the EDS data (but not shown), was the presence of a small amount of phosphorous on the surface of the alloys. Similar results of unpremeditated formation of $\mathrm{P}$ dopants and/or impurities were reported elsewhere [42].

In order to obtain further information about the surface of the alloy, XPS analysis was carried

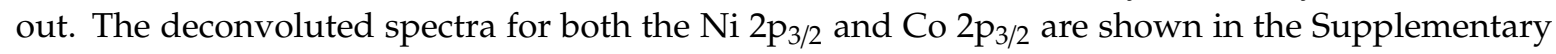
Information Figure S4. The spectra consist of both Ni and Co at various oxidation states. Ni peaks at binding energies of $852.81 \pm 0.1 \mathrm{eV}$ and $854.72 \pm 0.1 \mathrm{eV}$ are respectively attributed to metallic $\mathrm{Ni}^{0}$ and $\mathrm{Ni}^{2+}$ in the form of $\mathrm{NiO}$ [43]. The line centered at $856.05 \pm 0.1 \mathrm{eV}$ could either be due to $\mathrm{Ni}_{2} \mathrm{O}_{3}$ or $\mathrm{Ni}(\mathrm{OH})_{2}$ and a shake-up satellite peak at $861.26 \pm 0.1 \mathrm{eV}$ are within the reported literature values [44,45]. A small peak at $\mathrm{BE} 858.66 \pm 0.1 \mathrm{eV}$ can be denoted as the peak due to the alloying of $\mathrm{Ni}$ with secondary metal [46]. Five peaks are fitted for Co $2 \mathrm{p}_{3 / 2}$, where the main BE at $781.39 \pm 0.1 \mathrm{eV}$ and its ratio with corresponding satellite peak centered at $786.68 \pm 0.1 \mathrm{eV}$ indicate a $\mathrm{Co}^{3+}$ oxidation state and/or hydroxide form of Co $[47,48]$. The peak corresponding to metallic Co is observed at $777.91 \pm 0.1 \mathrm{eV}$, and the two other peaks fitted at $780.66 \pm 0.1 \mathrm{eV}$ and $784.11 \pm 0.1 \mathrm{eV}$ may be attributed to $\mathrm{Co}^{2+}$ oxide and the Co-Ni interaction [49]. The presence of oxides is unavoidable as the catalysts are stored and handled under ambient conditions. A surface pre-treatment is performed prior to the HOR measurements in half-cell, which is intended to reduce the metallic surface. The reducing environment under $\mathrm{H}_{2}$ in electrolyte should also be a favorable condition to control the surface passivation during the measurements. 

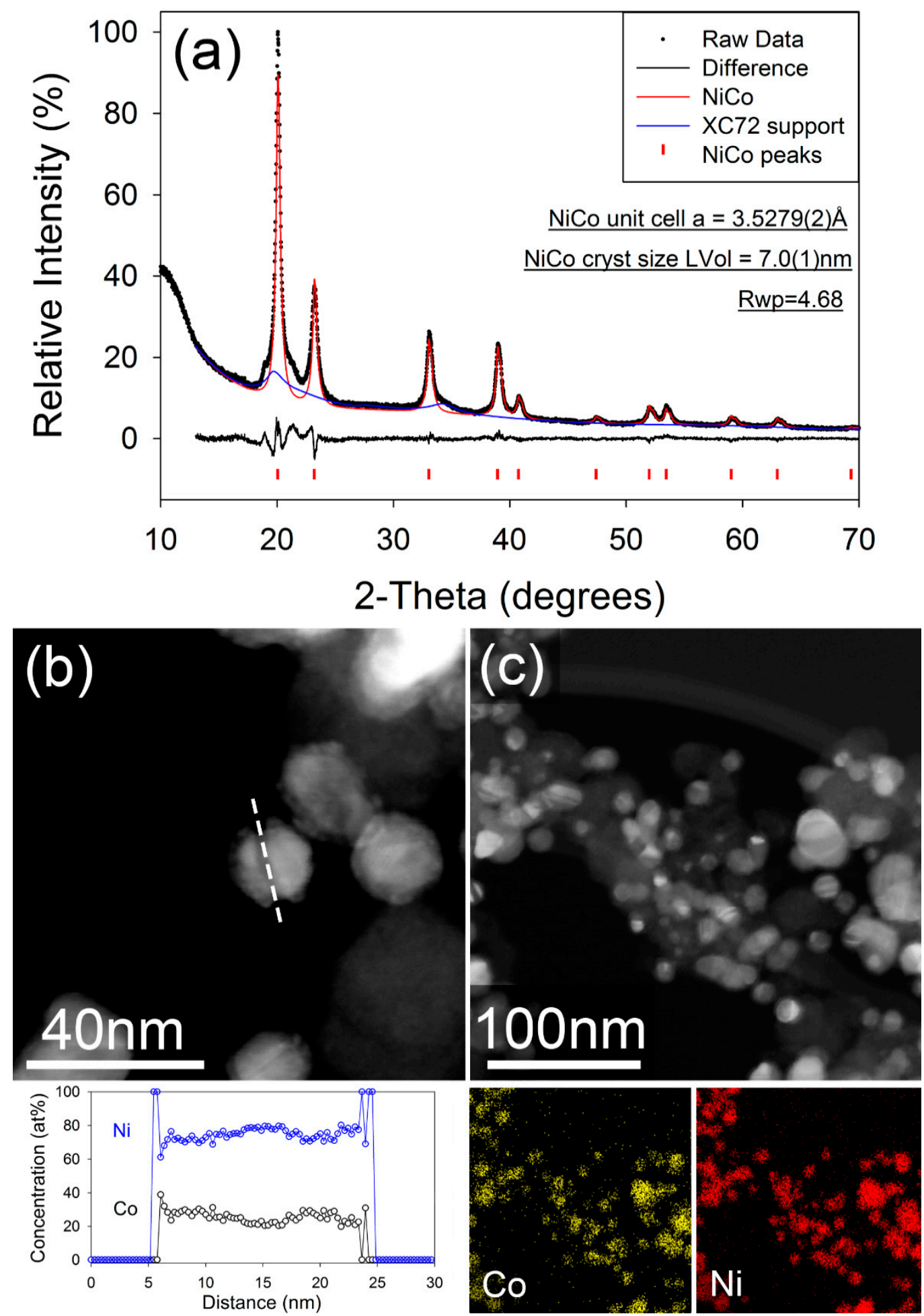

Figure 5. (a) Fitted X-ray diffraction pattern for $\mathrm{NiCo} \backslash \mathrm{C}$ after annealing. Data were collected in capillary transmission mode using a Mo- $\mathrm{K}_{\alpha}$ source and modelled using a Rietveld-type approach. (b) Dark field image of annealed $\mathrm{NiCo} / \mathrm{C}$ nanoparticles, with composition measured along the dashed line. (c) Dark field STEM image of annealed $\mathrm{NiCo} / \mathrm{C}$ nanoparticles with corresponding X-ray element maps of $\mathrm{Co}$ (yellow), and Ni (red). 


\subsection{Electrochemical Characterization}

\subsubsection{RRDE Characterization of $\mathrm{Co}_{3} \mathrm{O}_{4}$}

Figure 6a shows the cyclic voltammograms (CVs) and the ORR activity of the $\mathrm{Co}_{3} \mathrm{O}_{4}+\mathrm{C}$ composites compared to $\mathrm{Pt} / \mathrm{C}$ catalysts in Argon saturated 0.1 M KOH electrolyte. The shape and peak positions of the $\mathrm{Pt} / \mathrm{C} \mathrm{CV}$ is consistent with the literature on $\mathrm{Pt} / \mathrm{C}$ catalysts in $0.1 \mathrm{M} \mathrm{KOH}$. The two CVs of the $\mathrm{Co}_{3} \mathrm{O}_{4}$ catalyst, using two different catalyst loadings, differ considerably from the voltammogram of $\mathrm{Pt} / \mathrm{C}$ catalyst. $\mathrm{Co}_{3} \mathrm{O}_{4}$ show a typical double layer capacitive behavior and the absence of redox reactions. The absence of hydrogen absorption/desorption peaks, as well as Pt oxidation peaks are clear indications that there is no, or a negligible amount of dissolved $\mathrm{Pt}$ in the system that may have originated from $\mathrm{Pt}$ counter electrode dissolution and redeposition on the working electrode. It has recently been shown, that $\mathrm{Pt}$ dissolution of the counter electrode is considerably minimized in an alkaline environment [50]. It is, however, strongly recommended that for long-term measurements, recently recommended best practices are implemented [51].

The current density of the $460 \mu \mathrm{g} \mathrm{Co}_{3} \mathrm{O}_{4}$ electrode is approximately double the magnitude of the current density of the $230 \mu \mathrm{g} \mathrm{Co}_{3} \mathrm{O}_{4}$ electrode, which is consistent with expectations from doubling the electrode mass. Figure $6 \mathrm{c}$ shows the ORR activity in $\mathrm{O}_{2}$-saturated $0.1 \mathrm{M} \mathrm{KOH}$ solution with an anodic scan sweep taken at a rotating speed of $1600 \mathrm{rpm}$ and at $20 \mathrm{mV} \mathrm{s}^{-1}$. The $\mathrm{Pt} / \mathrm{C}$ showed the highest ORR onset potential of $0.854 \mathrm{~V}$ vs reversible hydrogen electrode (RHE), defined as the potential at $0.1 \mathrm{~mA} \mathrm{~cm}^{-2}$. Although this value is slightly lower compared to the optimized values of Campos-Roldan et al. [52], the activity is well within the values previously reported in the literature [52]. The PGM-free $\mathrm{Co}_{3} \mathrm{O}_{4}$ catalyst shows relatively good catalytic activity towards the ORR, with onset potentials of $0.684 \mathrm{~V}$ for both the $460 \mu \mathrm{g} \mathrm{Co}_{3} \mathrm{O}_{4}$ and $230 \mu \mathrm{g} \mathrm{Co} \mathrm{O}_{4}$ loadings. In these experiments, the addition of more catalyst does not seem to affect the catalytic activity at high potentials. But, the limiting current density increased significantly with the addition of more $\mathrm{Co}_{3} \mathrm{O}_{4}$ catalyst. Higher electrode loadings also influence the ring current, resulting in lower peroxide yields (Figure $6 \mathrm{~b}$ ). Calculated from the ring current of the $\mathrm{Pt} / \mathrm{C}$ electrode, the formation of $\mathrm{HO}_{2}{ }^{-}$by the four-electron reduction of $\mathrm{O}_{2}$ is obvious (electron transfer number of 3.99-3.98 going from high to low potentials). For the $\mathrm{Co}_{3} \mathrm{O}_{4}$ catalyst, however, the electron transfer number was lower at $\sim 3.98-3.92$ for the $460 \mu \mathrm{g} \mathrm{Co} \mathrm{O}_{4}$ electrode and $\sim 3.94-3.87$ for the $230 \mu \mathrm{g} \mathrm{Co} \mathrm{C}_{3}$. The mass activity, on the other hand, is considerably lower for $\mathrm{Co}_{3} \mathrm{O}_{4}$ catalysts as compared to $\mathrm{Pt} / \mathrm{C}$. At $0.85 \mathrm{~V}$ the mass activity for the $\mathrm{Pt} / \mathrm{C}$ is approximately $11 \mathrm{~A} \mathrm{~g}^{-1}$, whilst both $\mathrm{Co}_{3} \mathrm{O}_{4}$ electrodes, independent of the electrode loading, showed mass-activities three orders of magnitude lower than the $\mathrm{Pt} / \mathrm{C}$ catalysts, in the region of $0.06 \mathrm{~A} \mathrm{~g}^{-1}$.

\subsubsection{RDE Characterization of HOR Catalysts}

The catalytic activities of the $\mathrm{Pt} / \mathrm{C}, 10 \mathrm{wt} \% \mathrm{Pd} / \mathrm{C}-\mathrm{CeO}_{2}, \mathrm{FSP} \mathrm{Pd} / \mathrm{CeO}_{2}+\mathrm{C}$ and $\mathrm{NiCo} / \mathrm{C}$ catalysts towards HOR in 0.1M KOH are compared in Figure 7, Figures S5 and S6. Figure 7 shows the currents during a voltammetric scan at $5 \mathrm{mV} \mathrm{s}^{-1}$ in hydrogen-saturated solutions, with the catalysts deposited on a rotating disc electrode (RDE) rotating at $1600 \mathrm{rpm}$. The catalyst loading was $0.5 \mathrm{mg}$ metal for the $\mathrm{NiCo} / \mathrm{C}$ catalyst and $0.05 \mathrm{mg}$ for the PGM catalysts.

Currents normalized both with respect to the geometric surface area of the electrode (Figure 7a) and the mass of the catalyst deposited on the RDE (Figure $7 \mathrm{~b}$ ) are shown. The current normalized with respect to the geometric surface area is in the same order of magnitude for all catalysts. The $\mathrm{Pd} / \mathrm{CeO}_{2}$ catalysts and the $\mathrm{Pt} / \mathrm{C}$ catalysts display a similar performance overall, including a well-defined limiting current beyond $0.2 \mathrm{~V}$. The current from the $10 \mathrm{wt} \% \mathrm{Pd} / \mathrm{C}-\mathrm{CeO}_{2}$ catalyst, however, overshoots and displays a pronounced peak at $0.15 \mathrm{~V}$, beyond which it decreases to the same limiting current as the $\mathrm{FSP} \mathrm{Pd} / \mathrm{CeO}_{2}+\mathrm{C}$ and $\mathrm{Pt} / \mathrm{C}$ catalysts. Owing to the much larger mass of the $\mathrm{NiCo} / \mathrm{C}$ catalyst, the mass activity of this catalyst is much smaller than those of the other catalysts, as shown in Figure $7 \mathrm{~b}$. 

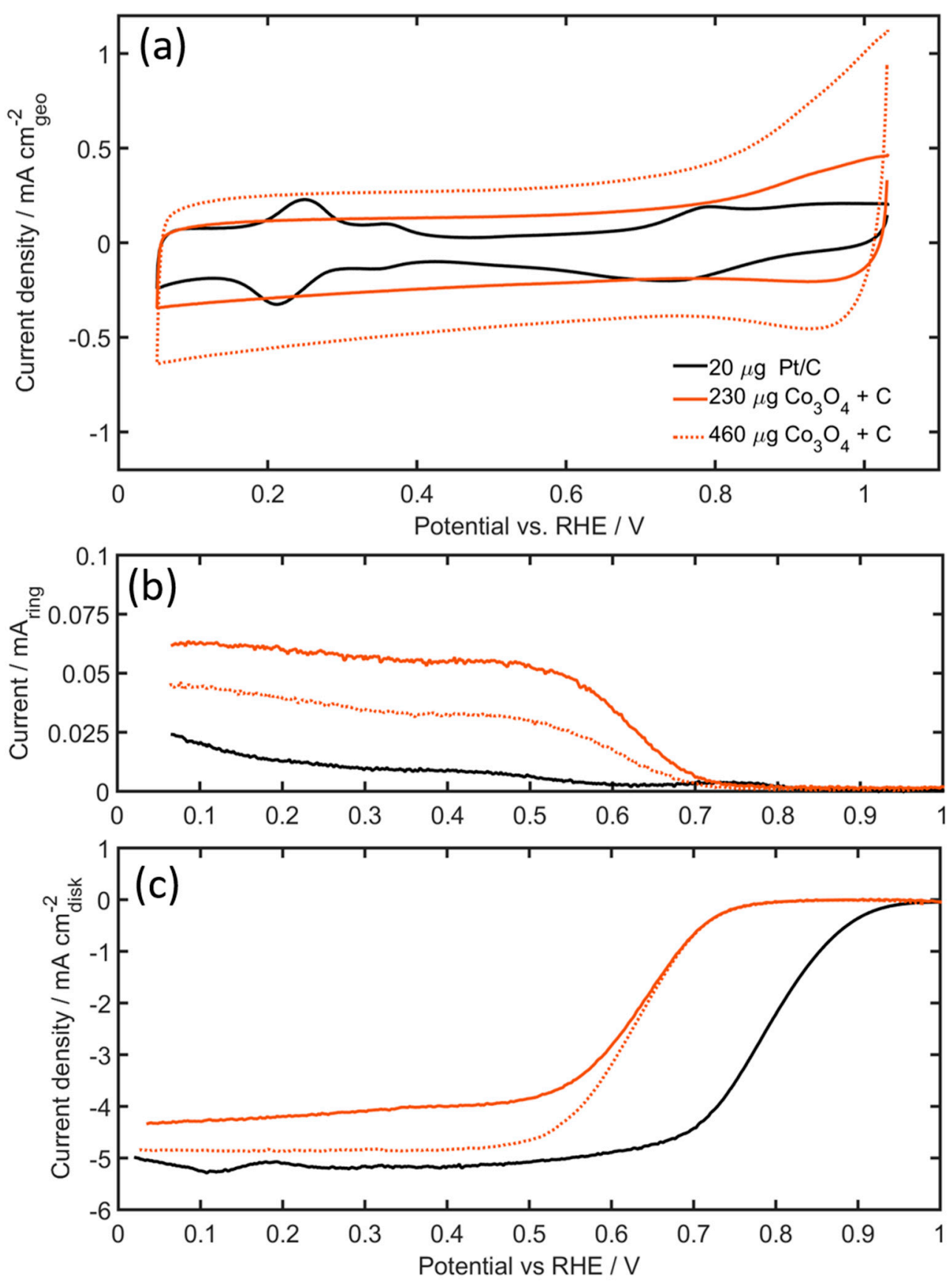

Figure 6. (a) Cyclic voltammograms of $\mathrm{Pt} / \mathrm{C}$ and $\mathrm{Co}_{3} \mathrm{O}_{4}+\mathrm{C}$ (catalyst/carbon ratio $=1.25$ ) in Ar-saturated electrolyte, (b) Rotating ring disk electrode (RRDE) ring current during ORR, and (c) disk current during ORR of $\mathrm{Pt} / \mathrm{C}$ and $\mathrm{Co}_{3} \mathrm{O}_{4}+\mathrm{C}$ (catalyst/carbon ratio $=1.25$ ) in $\mathrm{O}_{2}$-saturated electrolyte. Disk current are both $\mathrm{iR}$ corrected (using electrochemical impedance spectroscopy (EIS) and background corrected (using CV currents from Figure 6a). All measurements performed in $0.1 \mathrm{M} \mathrm{KOH}$, rotating speed: $1600 \mathrm{rpm}$, scan rate: $20 \mathrm{mVs}^{-1}$, using catalyst loadings of $20 \mu \mathrm{g} \mathrm{Pt}, 230$, and $460 \mu \mathrm{g} \mathrm{of} \mathrm{Co}_{3} \mathrm{O}_{4}$. 

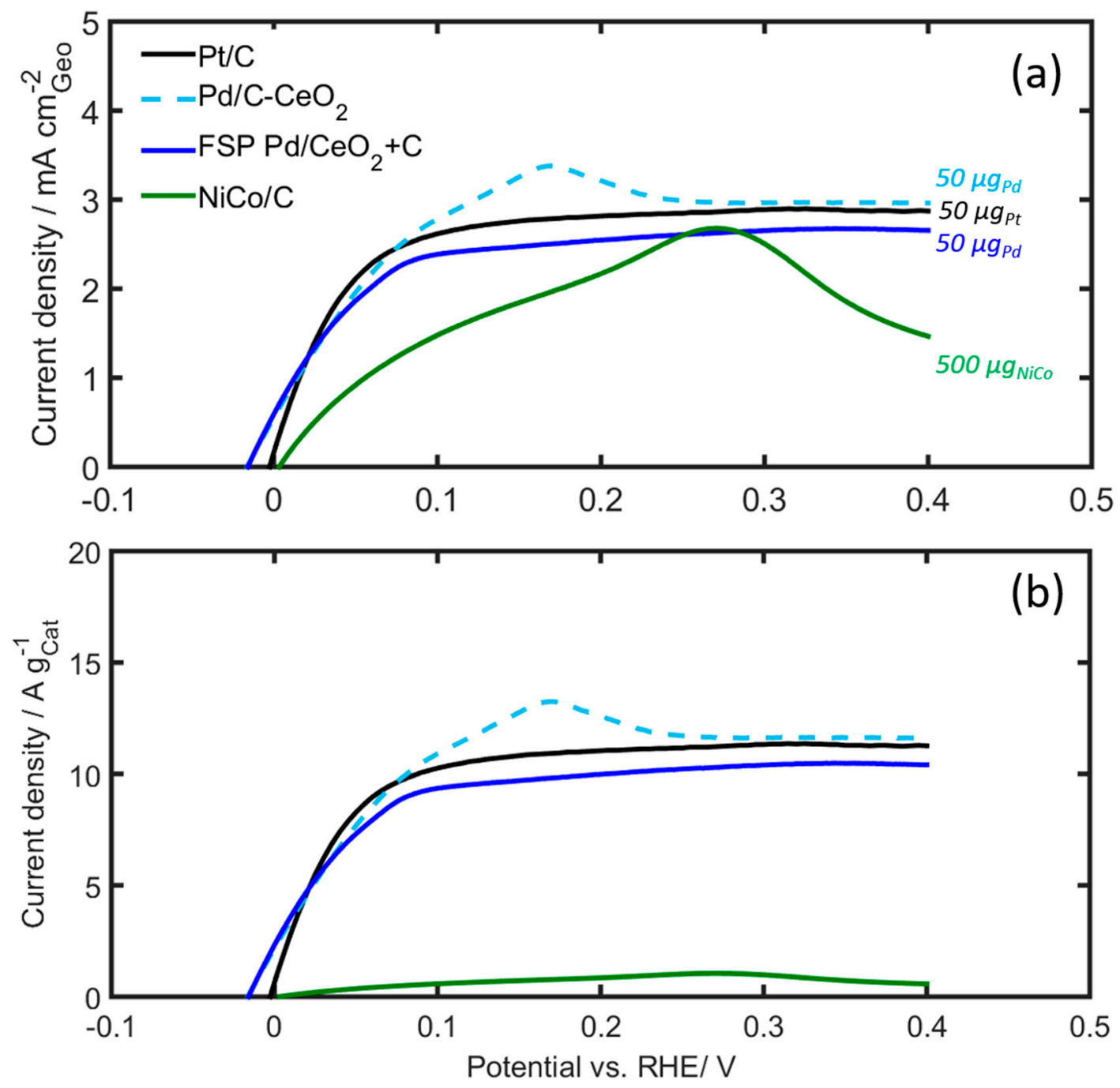

Figure 7. $\mathrm{RDE}$ voltammograms of $\mathrm{Pd} / \mathrm{C}-\mathrm{CeO}_{2}, \mathrm{Pd} / \mathrm{CeO}_{2}+\mathrm{C}$ and $\mathrm{NiCo} / \mathrm{C}$ compared to $\mathrm{Pt} / \mathrm{C}$ in $\mathrm{H}_{2}$-saturated 0.1 M KOH. (a) Geometric current density, and (b) mass specific current density. Scan rate: $5 \mathrm{mV} / \mathrm{s}$, rotating speed: $1600 \mathrm{rpm}$. The catalyst loading was $500 \mu \mathrm{g}$ based on NiCo, and $50 \mu \mathrm{g}$ for the PGM catalysts.

It is worth noticing that beyond $0.3 \mathrm{~V}$ there is a sharp decline in the observed $\mathrm{NiCo} / \mathrm{C}$ current (see Figure 7a), presumed to be due to reactions forming $\mathrm{NiOH}$ and $\mathrm{Ni}(\mathrm{OH})_{2}$ at the catalyst surface, which passivate the surface from further hydrogen oxidation [25,53]. Kabir, S. et al. [25] also observed a HOR current decay at potentials above $0.12 \mathrm{~V}$ for NiMo, without reaching the diffusion limiting value as observed for Pt electrodes. This was attributed to the blocking of the Ni surface by $\alpha-\mathrm{Ni}(\mathrm{OH})_{2}$. The authors also performed a micro kinetic model able to reproduce and explain these results. Recently, Davydova et al. [53] studied the stability of $\mathrm{Ni}_{3} \mathrm{M} / \mathrm{C}$ HOR catalysts $(\mathrm{M}=\mathrm{Co}, \mathrm{Fe}, \mathrm{Cu}, \mathrm{Mo})$ in alkaline medium, using in situ and ex situ techniques, as well as online ICP-MS. The results showed that no $\mathrm{Ni}$ or Co dissolution was observed from $\mathrm{Ni} / \mathrm{C}, \mathrm{Ni}_{3} \mathrm{Co} / \mathrm{C}$, still neither of the catalysts was found to be electrochemically active toward the HOR after prolonged potential cycling to a potential higher than $0.3 \mathrm{~V}$ vs RHE. The authors attribute these phenomena to a "dissolution-precipitation" mechanism that results in the formation of $\mathrm{Ni}(\mathrm{OH})_{2}$ layered octahedral sheets representing the most thermodynamically favored phase/crystal.

Figure $\mathrm{S} 5$ further shows the $\mathrm{CVs}$ of the $\mathrm{NiCo} / \mathrm{C}$ in $\mathrm{Ar}$ and $\mathrm{H}_{2}$-saturated solutions in more detail. The voltammograms in the Ar-sparged solutions demonstrate the typical features for bulk Ni [54,55], with forward wave peaking at $0.2 \mathrm{~V}$, representing the formation of $\alpha-\mathrm{Ni}(\mathrm{OH})_{2}$. On the reverse scan 
the current is small, negative and constant down to approximately $0.15 \mathrm{~V}$, at which point the onset of the reduction of $\alpha-\mathrm{Ni}(\mathrm{OH})_{2}$ appears and results in a cathodic peak at $0.05 \mathrm{~V}$. In the $\mathrm{H}_{2}$-saturated electrolyte, the current increased significantly in the forward scan, which we assign to the oxidation of $\mathrm{H}_{2}$. Here, the current increases until the potential reaches $0.21 \mathrm{~V}$. On the reverse scan in the hydrogen-saturated solution, the current is close to zero in the potential range $0.3 \mathrm{~V}$ through $0.15 \mathrm{~V}$, which is a good indication that the working electrode is not contaminated by the possible Pt dissolution from the counter electrode: Any redeposited $\mathrm{Pt}$ would have resulted in clear and high $\mathrm{H}_{2}$ oxidation currents. As the potential reaches $0.15 \mathrm{~V}$, an anodic wave appears in the $\mathrm{H}_{2}$-saturated electrolyte, also apparent on the return sweep, peaking at approximately $0.05 \mathrm{~V}$. The onset potential for the anodic wave on the return sweep is approximately the same as that for the reduction of $\alpha-\mathrm{Ni}(\mathrm{OH})_{2}$ in the voltammogram in the argon-saturated solution. We therefore associate the reverse-scan oxidation process with hydrogen oxidation at catalyst surface freed from $\alpha-\mathrm{Ni}(\mathrm{OH})_{2}$ as the potential is decreasing. The reverse-scan hydrogen oxidation wave coincides with the current in the forward sweep as the potential approaches zero.

\subsection{AEMFC Results}

Figure 8 shows the fuel cell polarization curves and power density curves obtained for the AEMFCs with the Pt-free and PGM-free catalysts. The cells are operated at $70{ }^{\circ} \mathrm{C}$ under $\mathrm{H}_{2}$ and $\mathrm{O}_{2}$ gases with controlled dew points of $68{ }^{\circ} \mathrm{C}$ and $73{ }^{\circ} \mathrm{C}$ for the anode and cathode, respectively. The PGM-free $\mathrm{Co}_{3} \mathrm{O}_{4}+\mathrm{C}$ shows good performance as a cathode catalyst, when using $\mathrm{Pt} / \mathrm{C}$ on the anode, and when compared to the PGM-Pt cathode only a $20 \mathrm{mV}$ difference at open circuit voltage (OCV) is observed, and approximately a $35 \mathrm{mV}$ difference at $50 \mathrm{~mA} \mathrm{~cm}{ }^{-2}$, see also Figure S7. It is noticed that the voltage difference is significantly smaller compared to the RDE measurements in liquid $\mathrm{KOH}$, which shows a $170 \mathrm{mV}$ difference at $10 \mathrm{~mA} \mathrm{~cm}^{-2}$ (see Figure 6c). Mamlouk et al. [15] reported similar results for their Co-based catalysts, e.g., a $50 \mathrm{mV}$ difference at $50 \mathrm{~mA} \mathrm{~cm}^{-2}$ between Co-based and $\mathrm{Pt}$ ORR catalysts in AEMFC, while observing a $120 \mathrm{mV}$ difference in RDE. Figure 8 further shows that at higher current densities, the cell voltage difference at $0.5 \mathrm{~A} \mathrm{~cm}^{-2}$ between the two cells is only $110 \mathrm{mV}$, i.e., $0.7 \mathrm{~V}$ and $0.59 \mathrm{~V}$, for the $\mathrm{Pt} / \mathrm{C}$ and $\mathrm{Co}_{3} \mathrm{O}_{4}+\mathrm{C}$ cathodes, respectively, clearly showing the potential for utilizing $\mathrm{Co}_{3} \mathrm{O}_{4}$ catalysts in AEMFCs cathodes as an alternative to PGM catalysts. The difference in performance is also reflected in the resulting peak power densities (Figure $8 \mathrm{~b}$ ). While the $\mathrm{Pt} / \mathrm{C}-\mathrm{Pt} / \mathrm{C}$ cell achieves $593 \mathrm{~mW} \mathrm{~cm}^{-2}$, the $\mathrm{Pt} / \mathrm{C}-\mathrm{Co}_{3} \mathrm{O}_{4}+\mathrm{C}$ cell reaches $388 \mathrm{~mW} \mathrm{~cm}^{-2}$. This is a AEMFC performance that can be regarded as excellent, especially when compared to other reported performance values using Co-based cathode catalysts [15].

For the Pt-free cells using $\mathrm{CO}_{3} \mathrm{O}_{4}+\mathrm{C}$ cathodes, the difference in performance between $\mathrm{FSP} \mathrm{Pd} / \mathrm{CeO}_{2}$ $+\mathrm{C}$ and $10 \mathrm{wt} \% \mathrm{Pd} / \mathrm{C}-\mathrm{CeO}_{2}$ catalysts is very small (see Figure $8 \mathrm{a}$ ). At $50 \mathrm{~mA} \mathrm{~cm}^{-2}$, both Pd-based anodes show a cell voltage of $0.81 \mathrm{~V}$, only $20 \mathrm{mV}$ lower compared to the $\mathrm{Pt} / \mathrm{C}$ anode. This is more clearly seen in Figure S7, which shows essentially identical mass activities above $0.8 \mathrm{~V}$ for these two Pt-free cells. This correlates well with the HOR activities measured in RDE (see Figure S6). At higher current densities the Pd-based AEMFCs also show excellent performance. At $0.5 \mathrm{~A} \mathrm{~cm}^{-2}$ the Pt/C, $\mathrm{FSP} \mathrm{Pd} / \mathrm{CeO}_{2}$ $+\mathrm{C}$ and $10 \mathrm{wt} \% \mathrm{Pd} / \mathrm{C}-\mathrm{CeO}_{2}$ anodes resulted in cell voltages of $0.59 \mathrm{~V}, 0.53 \mathrm{~V}$ and $0.47 \mathrm{~V}$, and peak power densities of $388,309,247 \mathrm{~mW} \mathrm{~cm}^{-2}$, respectively. It is also noted that the new FSP Pd/CeO $/ \mathrm{Catalyst}_{2}$ synthesized from the one-pot FSP is highly active for HOR in AEMFCs. The performance is comparable or slightly higher than the $10 \mathrm{wt} \% \mathrm{Pd} / \mathrm{C}-\mathrm{CeO}_{2}$, which is considered to be the state-of-the-art Pt-free catalyst for AEMFCs [21]. Figure 8 and Figure $\mathrm{S} 7$ also show the performance of the PGM-free AEMFC based on the $\mathrm{NiCo} / \mathrm{C}$ anode and $\mathrm{Co}_{3} \mathrm{O}_{4}+\mathrm{C}$ cathode. The totally PGM-free cell achieves a peak power density of $22.1 \mathrm{mWcm}^{-2}$. Although this is a lower performance compared to the PGM based cells, the performance is in the same order of magnitude compared to other reported values in the literature for similar PGM free cells $[23,24]$. Comparing our AEMFC result using the NiCo-based anode with the RDE results, it is suggested that the performance of the NiCo AEMFC anode could be limited by mass transfer: While the RDE measurements show the NiCo catalysts having mass activities for the HOR in 
the same order of magnitude as the PGM-based $\mathrm{Pd} / \mathrm{CeO}_{2}$ catalysts, e.g., 0.02 and $0.06 \mathrm{~mA} \mathrm{mg}^{-1}$ metal at $0.05 \mathrm{~V}$ vs RHE, respectively, the mass activity is at least two orders of magnitude lower when the catalyst is used as an AEMFC anode (see Figures S6 and S7). In both cases the NiCo catalyst loading is approximately 10 times the loading of the PGM catalysts, e.g., RDE loadings of $500 \mu \mathrm{g}$ Ni and $50 \mu \mathrm{g} \mathrm{Pd}$, and AEMFC anode loadings of $5 \mathrm{mg} \mathrm{cm}^{-2} \mathrm{NiCo}$ and $0.5 \mathrm{mg} \mathrm{cm}^{-2} \mathrm{Pd}$. The NiCo is therefore applied in much thicker catalyst layers with longer diffusion distances, which may in turn result in AEMFC anodes more sensitive to electrode flooding in the presence of liquid water [56].
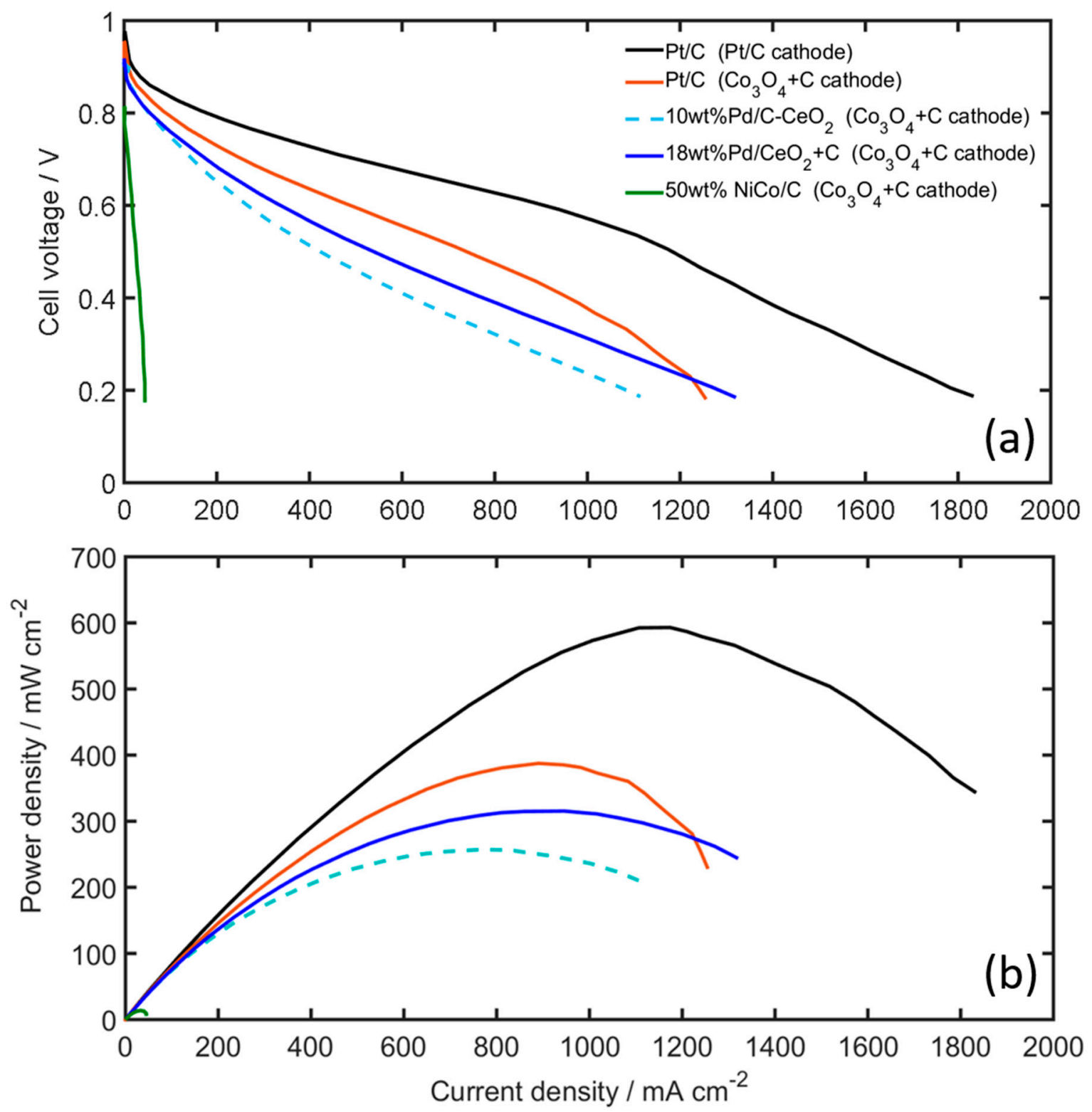

Figure 8. (a) Polarization, and (b) power density curves of the AEMFC using various anode and cathode catalysts (cathodes are denoted within parenthesis in the legend). Measurements taken at $70{ }^{\circ} \mathrm{C}, \mathrm{H}_{2}$ and $\mathrm{O}_{2}$ on anode and cathode, using 1.0 and $0.5 \mathrm{slpm}$, respectively. Gas dew points are 68 and $73^{\circ} \mathrm{C}$ for the anode and cathode, respectively. 


\section{Experimental}

\subsection{Catalyst Synthesis}

\subsubsection{Synthesis of $\mathrm{Co}_{3} \mathrm{O}_{4}$}

Synthesis of fine powders of $\mathrm{Co}_{3} \mathrm{O}_{4}$ with nanoscale crystallinity was achieved via a modified version of the multi-stage method reported by Zhao-Qing et al. [57]. In the first stage, $90 \mathrm{~mL}$ of a $0.1 \mathrm{M}$ (cobalt basis) solution of Cobalt Nitrate hexahydrate $\left(\mathrm{Co}\left(\mathrm{NO}_{3}\right)_{2} \cdot 6 \mathrm{H}_{2} \mathrm{O}\right)$ and Urea $\left(\mathrm{NH}_{2} \mathrm{CONH}_{2}\right)$ at a molar ratio 1:5 of Co:Urea was placed in a PTFE-lined, $200 \mathrm{~mL}$ volume hydrothermal cell. This was reacted at $120^{\circ} \mathrm{C}$ for $12 \mathrm{~h}$ and cooled to room temperature under ambient room conditions. This yielded a product phase of $\mathrm{Co}_{2}\left(\mathrm{CO}_{3}\right) \mathrm{OH}_{2}$, which was washed with water to remove reaction residues. This powder was then ball-milled using spherical $5 \mathrm{~mm}$ zirconia milling media on a roller type mill to break down particle agglomerates. The milled powder was separated from the milling media, dried and decomposed via heat treatment at $250{ }^{\circ} \mathrm{C}$ in air to yield a final product phase of $\mathrm{Co}_{3} \mathrm{O}_{4}$. The final catalyst was produced at the ink preparation stage via mixing of $\mathrm{Co}_{3} \mathrm{O}_{4}$ with Vulcan $\mathrm{XC}-72$ in a 50:50 ratio.

\subsubsection{Synthesis of $10 \mathrm{wt} \% \mathrm{Pd} / \mathrm{C}-\mathrm{CeO}_{2}$ by Wet Chemistry}

The synthesis and characterization of this state-of-the-art $\mathrm{Pd} / \mathrm{C}-\mathrm{CeO}_{2}$ has been reported in detail elsewhere [18]. In summary, a composite consisting of $\mathrm{C}$ and $\mathrm{CeO}_{2}$ was made by the addition of Vulcan XC-72 to a solution of $\mathrm{Ce}\left(\mathrm{NO}_{3}\right)_{3} \cdot 6 \mathrm{H}_{2} \mathrm{O}$ in $\mathrm{H}_{2} \mathrm{O}$. The mixture was kept under stirring and sonication, the $\mathrm{pH}$ was adjusted to 12 with $\mathrm{KOH}$, and the resulting suspension was stirred for $2 \mathrm{~h}$. The product was separated by filtration and washed with $\mathrm{H}_{2} \mathrm{O}$ until a neutral $\mathrm{pH}$ was obtained. The product was then dried at $65{ }^{\circ} \mathrm{C}$, and subsequently heated under air in a tube furnace at $250^{\circ} \mathrm{C}$ for $2 \mathrm{~h}$. Cooling to room temperature was undertaken under a flow of Ar. The $\mathrm{C}-\mathrm{CeO}_{2}(4 \mathrm{~g})$ composite was then suspended in water $(500 \mathrm{~mL})$, stirred vigorously for $30 \mathrm{~min}$ and sonicated for $20 \mathrm{~min}$. To this mixture, a solution of $\mathrm{K}_{2} \mathrm{PdCl}_{4}(1.38 \mathrm{~g})$ in water $(60 \mathrm{~mL})$ was slowly added (during $\left.\sim 1 \mathrm{~h}\right)$ under vigorous stirring, followed by addition of an aqueous solution of $2.5 \mathrm{M} \mathrm{KOH}(8.4 \mathrm{~mL})$. Next, ethanol $(50 \mathrm{~mL})$ was added and the resulting mixture was heated at $80{ }^{\circ} \mathrm{C}$ for $60 \mathrm{~min}$. The desired product of $10 \mathrm{wt} \% \mathrm{Pd} / \mathrm{C}-\mathrm{CeO}_{2}$ was filtered off, washed several times with distilled water to neutrality, and finally dried under vacuum at $65^{\circ} \mathrm{C}$ until constant weight was reached.

\subsubsection{Synthesis of FSP Pd/CeO $2+C$ by Flame Spray Pyrolysis (FSP)}

Nanoscale composite powders of $\mathrm{Pd} / \mathrm{CeO}_{2}$ were synthesized via single stage flame spray pyrolysis (FSP) of flammable precursor reagents: Appropriate stoichiometric quantities of Palladium Trimethyl Acetate and Cerium (II) 2-ethylhexanoate (49\%) in 2-ethylhexanoic acid to produce an $18 \mathrm{wt} \% \mathrm{Pd} / \mathrm{CeO}_{2}$ mixture were dissolved in xylene at a concentration of $0.13 \mathrm{M}$ (total metals basis). Using a Tethis Nanotech NPS10 FSP unit, this solution was then atomized into a flame under a constant flow of air, which resulted in rapid high temperature combustion and atomization of the metal species. The product phases formed on cooling were collected from the airstream using a PTFE filter with $\sim 0.5 \mu \mathrm{m}$ pore size. For electrochemical testing the as-synthesized catalyst was mixed with Vulcan XC-72 during ink production. For RDE measurements a 50:50 ratio with XC72 was used, giving a 9.1:50:41.9 ratio of $\mathrm{Pd}: \mathrm{C}: \mathrm{CeO}_{2}$. For full cell testing a ratio of 55:45 was used, giving a comparable 10:45:45 $\mathrm{Pd} / \mathrm{C} / \mathrm{CeO}_{2}$ ratio to that of the state-of-the-art $(\mathrm{SoA}) \mathrm{Pd} / \mathrm{C}-\mathrm{CeO}_{2}$ catalyst produced via wet chemistry.

\subsubsection{Synthesis of $\mathrm{NiCo} / \mathrm{C}$}

The synthesis procedure for carbon-supported NiCo nanoparticles was adapted from that reported procedure [58] for the synthesis of monodispersed nickel nanoparticles. Stoichiometric quantities of Nickel (II) acetylacetonate $(2.54 \mathrm{mmol})$, Cobalt (II) acetylacetonate $(0.847 \mathrm{mmol})$ and VXC-72 carbon $(200 \mathrm{mg})$ were mixed in a round-bottomed flask with oleylamine $(63.8 \mathrm{mmol})$ and trioctylphosphine 
(20.17 mmol), to give a final composition $\mathrm{Ni}_{0.75} \mathrm{Co}_{0.25}$ supported on carbon. Under an Ar atmosphere, the mixture was degassed for $30 \mathrm{~min}$ at $100{ }^{\circ} \mathrm{C}$, then heated at a rate of $5{ }^{\circ} \mathrm{C} \mathrm{min}$ m $^{-1}$ to $210{ }^{\circ} \mathrm{C}$ and held for $45 \mathrm{~min}$. After cooling to room temperature, the resulting dispersion was washed multiple times with toluene and isopropyl alcohol with centrifugation, with a final wash of toluene and acetone. The resulting fine black powder was dried under vacuum and annealed for $2 \mathrm{~h}$ at $500{ }^{\circ} \mathrm{C}$ under an atmosphere of $5 \% \mathrm{H}_{2}$ in Ar.

\subsection{Physical Characterization}

\subsubsection{XRD}

X-ray diffraction was used to evaluate the crystallinity and phase composition of the catalysts and intermediates. Data were collected in transmission capillary mode using a Bruker D8 Advance A25 diffractometer, utilizing a Mo-K $\alpha$ source, focusing Göbel mirror, and LynxEye XE ${ }^{\mathrm{TM}}$ detector. The phases were identified via matching with the ICDD PDF4+ (2017) database, and Whole Powder Pattern Modelling (WPPM) performed with the Bruker DiffracTopas v5 software suite. Crystallite sizes were calculated via the Integral Breadth method within the WPPM. For the carbon-supported NiCo nanoparticle sample, in order to correctly model the contribution of the carbon support, a separate scan was taken of the support, and a structureless model determined. This was included (with scaling) in the fitting of the supported NiCo.

\subsubsection{TEM}

Catalyst powders were prepared for transmission electron microscopy (TEM) by ultrasonication in isopropanol and dispersion on $\mathrm{Cu}$ grids with lacey carbon support film. Imaging was performed using three electron microscopes, a 30 kV, Hitachi S-5500 SEM/STEM, a 200 kV JEOL JEM-2100F and a $200 \mathrm{kV}$ probe/image-corrected JEOL ARM-200F. Spectrum imaging using energy-dispersive X-ray spectroscopy (EDX) was performed on both the ARM-200F and JEM-2100F, and Electron Energy Loss Spectroscopy (EELS) was performed on the ARM-200F.

\subsubsection{XPS}

The X-ray Photoelectron Spectroscopy (XPS) measurements were recorded on a Kratos Analytical Axis Ultra DLD instrument with a monochromatized $\mathrm{Al} \mathrm{K}_{\alpha}$ X-ray source. A pass energy of $160 \mathrm{eV}$ was used for survey scans in the range of 0-1200 eV. Detailed scans were conducted at a pass energy of $20 \mathrm{eV}$ using a step size of $0.1 \mathrm{eV}$. The measured spectra were analyzed using casa XPS software (version 2.3.19), and a Lorentzian asymmetric (LA) line shape was used for each component. For measurement, the $\mathrm{Pd}-\mathrm{CeO}_{2}$ samples were dispersed on a borosilicate glass slide using high purity iso-propanol and were charge-neutralized during measurement using low energy electrons. For the $\mathrm{Pd}-\mathrm{CeO}_{2}$ sample binding energies were calibrated to the strong $\mathrm{O} 1 \mathrm{~s}(532.9 \mathrm{eV})$ line from the silicate substrate, whilst for NiCo adventitious carbon $(284.8 \mathrm{eV})$ was used.

\subsection{Rotating Disk Electrode (RDE) Characterization}

Electrochemical catalyst characterization was performed using PINE Research RDE equipment. Measurements were performed in a PTFE cell using $0.1 \mathrm{M} \mathrm{KOH}$ solutions. A standard single junction $\mathrm{Hg} / \mathrm{HgO}$ was used as the reference electrode, and a Pt foil was used as the counter electrode. All potentials were corrected to a standard reversible hydrogen electrode (RHE) by experimentally calibrating the $\mathrm{Hg} / \mathrm{HgO}$ in hydrogen saturated $0.1 \mathrm{M} \mathrm{KOH}$ using a Pt electrode. A glassy carbon electrode (5 mm dia., $0.196 \mathrm{~cm}^{2}$ geometrical surface area) embedded in a Teflon tip was used as the working electrode. The electrocatalytic activity of all catalysts was measured using a thin film approach where a catalyst suspension in $\mathrm{H}_{2} \mathrm{O}$, isopropyl alcohol and Nafion was drop-cast on the glassy carbon electrode and dried under a flow of Ar gas. For the determination of HOR and ORR activities, 99.999\% purity $\mathrm{H}_{2}$, and $99.9999 \%$ purity $\mathrm{O}_{2}$ gases were used, respectively. Cycle voltammetry (CV) experiments 
were recorded using $99.9999 \%$ purity Ar. The catalyst inks were prepared by taking an aliquot of $5 \mathrm{mg}$ of the catalyst powder and suspended in a mixture of $\mathrm{H}_{2} \mathrm{O}$, isopropyl alcohol $\left(\mathrm{H}_{2} \mathrm{O}\right.$ : IPA, 1:1) and $30 \mu \mathrm{L}$ of a $5.0 \% w / w$ lower aliphatic alcohol-water solution of Nafion (EW: 1100, Aldrich). After sonication for $30 \mathrm{~min}$, the suspension $\left(500 \mu \mathrm{g}_{\mathrm{Ni}} \mathrm{cm}^{-2}\right)$ was dropped onto the GC electrode and dried at vacuum/nitrogen $\left(\mathrm{N}_{2}\right)$. Both $10 \mathrm{wt} \% \mathrm{Pd} / \mathrm{C}-\mathrm{CeO}_{2}$, and $\mathrm{FSP} \mathrm{Pd} / \mathrm{CeO}_{2}+\mathrm{C}$ catalyst inks were made in a similar way to $\mathrm{NiCo} / \mathrm{C}$, by keeping the loading as $50 \mu \mathrm{g}_{\mathrm{Pd}} \cdot \mathrm{cm}^{-2}$. The $\mathrm{VXC}-72$ carbon $(50 \%)$ was physically mixed with the FSP $\mathrm{Pd} / \mathrm{CeO}_{2}$ while making the catalyst ink. For the ORR tests, the working electrode was preconditioned by cyclic sweeps from $0.05 \mathrm{~V}$ to $1.03 \mathrm{~V}$ vs RHE in an already Ar-purged electrolyte (purged for $30 \mathrm{~min}$ ) at $100 \mathrm{mV} / \mathrm{s}$ for 40 sweeps, and at $10 \mathrm{mV} / \mathrm{s}$ for 5 sweeps. The background (capacitance) current was measured at $20 \mathrm{mV} / \mathrm{s}$ for 20 sweeps with an electrode rotation of $1600 \mathrm{rpm}$. EIS measurements between $10 \mathrm{kHz}$ and $1 \mathrm{~Hz}$ at $0.5 \mathrm{~V}$ vs RHE with an amplitude of $0.01 \mathrm{~V}$ were conducted to correct for the $\mathrm{iR}$ contribution. Both the background and $\mathrm{iR}$ contributions were later subtracted from the raw data. The ORR measurements were carried out 5 times between $1.03 \mathrm{~V}$ and $0.05 \mathrm{~V}$ vs RHE at $20 \mathrm{mV} / \mathrm{s}$ with an electrode rotation of $1600 \mathrm{rpm}$, and the Pt-ring potential was set to $1.2 \mathrm{~V}$ vs RHE. Similarly, for the HOR tests, the working electrodes were preconditioned by cycling the potential between -0.2 and $0.4 \mathrm{~V}$ vs RHE for 50 cycles in an Ar-purged electrolyte and kept under an Ar atmosphere at a sweep rate of $20 \mathrm{mV} \mathrm{s}^{-1}$. The Ar atmosphere and the upper potential limit was selected in order to minimize possible effects of surface passivation on the catalysts. After the preconditioning, CVs were collected by sweeping the potential between -0.06 and $0.4 \mathrm{~V}$ at $1 \mathrm{mVs}^{-1}$ under similar conditions (argon sparging and atmosphere). The electrolyte was subsequently saturated with $\mathrm{H}_{2}$, and the $\mathrm{HOR}$ polarization curves were recorded in the potential range -0.06 through $0.4 \mathrm{~V}$ at a scan rate of $1 \mathrm{mVs}^{-1}$ with the electrode rotating at $1600 \mathrm{rpm}$. The solutions were continuously sparged with $\mathrm{H}_{2}$ during these experiments. In addition, the HOR activity was further assessed by linear sweep voltammetry (LSV) in the hydrogen-saturated electrolyte. For these LSVs the scan rate was $5 \mathrm{mVs}^{-1}$ and the potential range was from -0.06 through $0.4 \mathrm{~V}$. LSVs were recorded at a range of rotation speeds from 400 through $2400 \mathrm{rpm}$.

\subsection{Membrane Electrode Assembly (MEA) Preparation and Evaluation}

Gas diffusion layers (GDLs)_GDL340 carbon paper with micro porous layer (MPL) supplied by CeTech Co., Ltd., (Taiwan, China) were selected as GDLs for both anode and cathode sides, similar to those used in our previous study [16]. The GDL properties are summarized in Table 2. The anion exchange membrane (AEM) and ionomer used were AT-1 and aQAPS-S ${ }_{14}$, respectively (supplied by Hephas Energy Co., (China). The AT-1 membrane with a thickness of 30-40 $\mu \mathrm{m}$ in the dry form has a specific ion conductivity of ca. $0.1 \mathrm{~S} \mathrm{~cm}^{-1}$ at $60^{\circ} \mathrm{C}$. The main structure of AT- 1 membrane and aQAPS-S-14 ionomer contains quaternary ammonium groups, enabling the bonding of polysulfone backbone via $\mathrm{CH}_{2}$ bridges and the attachment of hydrophobic side chains onto the backbone to obtain the ion-aggregating structure [59].

Table 2. Physical properties of GDL340.

\begin{tabular}{|c|c|c|c|c|c|c|c|c|}
\hline \multirow{2}{*}{$\begin{array}{l}\text { Thickness } \\
\text { (mm) }\end{array}$} & \multicolumn{2}{|c|}{ PTFE (wt \%) } & \multirow{2}{*}{$\begin{array}{c}\text { Air } \\
\text { Permeability } \\
\text { (s) }\end{array}$} & \multirow{2}{*}{$\begin{array}{c}\text { Through Plane } \\
\text { Resistance } \\
\left(\mathrm{m} \Omega \mathrm{cm}^{2}\right)\end{array}$} & \multirow{2}{*}{$\begin{array}{c}\text { Mean Pore } \\
\text { Diameter } \\
(\mu \mathrm{m})\end{array}$} & \multirow{2}{*}{$\begin{array}{c}\text { Porosity } \\
\text { (\%) }\end{array}$} & \multicolumn{2}{|c|}{ Contact Angle $\left({ }^{\circ}\right)$} \\
\hline & MPL & Back & & & & & MPL & Back \\
\hline 0.31 & 30 & 30 & 99.5 & 11.9 & 36.69 & 64.06 & 146.2 & 147.5 \\
\hline
\end{tabular}

The catalyst ink was prepared by blending the corresponding catalyst powders with $20 \mathrm{wt} \%$ aQAPS-S $_{14}$ ionomer (2 wt \% DMF). The catalyst and ionomer were mixed with deionized (DI) water and isopropyl alcohol (IPA) with a volume ratio of 1:1 as dispersant/solvent, according to previous ink compositions and preparation methods [60]. For the FSP Pd/CeO 2 and $\mathrm{Co}_{3} \mathrm{O}_{4}$ catalysts, 50 wt \% carbon supports (Vulcan XC-72) was added during catalyst ink preparation to form $\mathrm{Co}_{3} \mathrm{O}_{4}+\mathrm{C}$ and $\mathrm{Pd} / \mathrm{CeO} 2+$ $\mathrm{C}$ composites, respectively. As an example, a typical FSP Pd/CeO $\mathrm{Ce}_{2} \mathrm{C}$ catalyst ink preparation was made by mixing $29.6 \mathrm{mg}$ carbon dispersed into $865 \mathrm{mg}$ DI water and sonicated for $30 \mathrm{~min}$. An amount 
of $36.1 \mathrm{mg}$ of $18 \mathrm{wt} \% \mathrm{Pd} / \mathrm{CeO}_{2}$ was then added to the carbon dispersion and sonicated for an additional $30 \mathrm{~min}$. Then, $657 \mathrm{mg}$ of ionomer was added to the suspension, followed by adding $865 \mathrm{mg}$ IPA. The mixture was sonicated for $60 \mathrm{~min}$ before spray coating it onto a $13 \mathrm{~cm}^{2}$ GDL340 surface on a hot plate pre-heated at $80^{\circ} \mathrm{C}$. For comparative purposes, an MEA prepared with $40 \% \mathrm{Pt} / \mathrm{C}$ (Tanaka) on both anode and cathode was also prepared. The catalyst loadings of each AEMFC are presented in Table 3.

Table 3. Anode and cathode composition of tested membrane electrode assemblies (MEAs).

\begin{tabular}{ccccccccc}
\hline Tittle & \multicolumn{3}{c}{ Anodes } & \multicolumn{4}{c}{ Cathodes } \\
\hline Cell & Catalyst & $\begin{array}{c}\text { Pt, Pd or NiCo } \\
\text { Loading } \\
\left(\mathbf{m g ~ c m}^{-2}\right)\end{array}$ & $\begin{array}{c}\text { Carbon/Ceria } \\
\text { Loading } \\
\left(\mathbf{m g ~ c m}^{-2}\right)\end{array}$ & $\begin{array}{c}\text { Ionomer } \\
\text { Loading } \\
\left(\mathbf{m g ~ c m}^{-2}\right)\end{array}$ & Catalyst & $\begin{array}{c}\mathbf{P t}_{\text {or } \mathbf{C o}_{3} \mathrm{O}_{4}}^{\text {Loading }} \\
\left(\mathbf{m g ~ c m}^{-2}\right)\end{array}$ & $\begin{array}{c}\text { Carbon } \\
\text { Loading } \\
\left(\mathbf{m g ~ c m}^{-2}\right)\end{array}$ & $\begin{array}{c}\text { Ionomer } \\
\text { Loading } \\
\left(\mathbf{m g ~ c m}^{-2}\right)\end{array}$ \\
\hline $\mathbf{1}$ & $40 \% \mathrm{Pt} / \mathrm{C}$ & 0.5 & 0.75 & 0.25 & $40 \% \mathrm{Pt} / \mathrm{C}$ & 0.5 & 0.75 & 0.25 \\
\hline $\mathbf{2}$ & $40 \% \mathrm{Pt} / \mathrm{C}$ & 0.5 & 0.75 & 0.25 & $\mathrm{Co}_{3} \mathrm{O}_{4}+\mathrm{C}$ & 3 & 3 & 1.2 \\
\hline $\mathbf{3}$ & $\begin{array}{c}10 \% \mathrm{Pd} / \mathrm{C} \\
\mathrm{CeO}_{2}\end{array}$ & 0.5 & $2.25 / 2.25$ & 1 & $\mathrm{Co}_{3} \mathrm{O}_{4}+\mathrm{C}$ & 3 & 3 & 1.2 \\
\hline $\mathbf{4}$ & $\begin{array}{c}18 \% \\
\mathrm{Pd} / \mathrm{CeO}_{2}+\mathrm{C}\end{array}$ & 0.5 & $2.27 / 2.27$ & 1 & $\mathrm{Co}_{3} \mathrm{O}_{4}+\mathrm{C}$ & 3 & 3 & 1.2 \\
\hline $\mathbf{5}$ & $50 \% \mathrm{NiCo} / \mathrm{C}$ & 5.0 & 5 & 5 & $\mathrm{Co}_{3} \mathrm{O}_{4}+\mathrm{C}$ & 3 & 3 & 1.2 \\
\hline
\end{tabular}

In order to ion exchange the membranes into the hydroxide form, the as-received membranes were pre-treated by soaking in $1 \mathrm{M} \mathrm{KOH}$ for at least $48 \mathrm{~h}$ at $60^{\circ} \mathrm{C}$. The prepared gas diffusion electrodes (GDEs) were also dipped in $1 \mathrm{M} \mathrm{KOH}$ solution for $24 \mathrm{~h}$ before the assembly of the AEMFC. Finally, the AT-1 AEM was sandwiched with two prepared GDEs with $10.24 \mathrm{~cm}^{-2}$ active area. The obtained MEAs were sandwiched between two graphite plates with triple serpentine flow fields ( $1 \mathrm{~mm}$ channel width and height, $1.5 \mathrm{~mm}$ land width) and gold-coated copper current collector plates, 250-300 $\mu \mathrm{m}$ thick Teflon gaskets, and compressed using $1.47 \mathrm{~N} \mathrm{~m}$ of torque to each of the eight screws. A fuel cell testing system (FCED-PD50 test station, Asia Pacific Fuel Cell Technologies, Ltd.) was employed. The polarization curves were recorded while operating the cell under 1.0 and 0.5 slpm of $\mathrm{H}_{2}$ and $\mathrm{O}_{2}$, respectively.

\section{Conclusions}

This paper presents our research progress in developing Pt-free and PGM-free catalysts used in AEMFCs. Non-noble $\mathrm{Co}_{3} \mathrm{O}_{4}$ catalysts with nanoscale crystallinity and an anisotropic platelet morphology have been synthesized via a scalable process. Although less active compared to the PGM-based Pt/C catalyst according to the RRDE experiments, these $\mathrm{Co}_{3} \mathrm{O}_{4}$ catalysts show an excellent AEMFC performance, with only a $100 \mathrm{mV}$ decrease at $0.5 \mathrm{~A} \mathrm{~cm}^{-2}$ measured relative to $\mathrm{Pt} / \mathrm{C}$.

The scalable FSP synthesis of an extremely active nano-scaled $\mathrm{Pd} / \mathrm{CeO}_{2}$ material is also reported. This material shows no apparent Pd crystallinity and extremely small $(\sim 1 \mathrm{~nm}) \mathrm{Pd}$ nanoparticles. The XPS data of the FSP-synthesized $\mathrm{Pd} / \mathrm{CeO}_{2}$ shows no evidence of metallic $\mathrm{Pd}$, and only a weak signal which may be attributed to a PdO-type Pd(II). Although not conclusively proven, the FSP $\mathrm{Pd} / \mathrm{CeO}_{2}$ may present $\mathrm{Pd}^{4+}$ bulk oxide and/or some interaction between the catalyst and $\mathrm{CeO}_{2}$ support. Nevertheless, the FSP Pd/CeO $+\mathrm{C}$ catalyst showed consistently excellent catalytic activity towards the $\mathrm{HOR}$, performing just as well as, or better than, the state-of-the-art $10 \mathrm{wt} \% \mathrm{Pd} / \mathrm{C}-\mathrm{CeO}_{2}$ catalyst in both RDE and AEMFC measurements. AEMFC tests using FSP Pd/CeO $\mathrm{Ce}_{2}+\mathrm{C}$ and $\mathrm{Co}_{3} \mathrm{O}_{4} / \mathrm{C}$ as the anode and cathode catalysts, respectively, achieved a peak power density as high as $308 \mathrm{~mW} \mathrm{~cm}{ }^{-2}$.

Monodispersed $\mathrm{NiCo}$ nanoparticles supported on carbon $(\mathrm{NiCo} / \mathrm{C})$ are shown to perform in the same order of magnitude as for the Pt and Pd based HOR catalysts in RDE below $0.3 \mathrm{~V}$. However, beyond $0.3 \mathrm{~V}$ there is a sharp decline in the $\mathrm{NiCo} / \mathrm{C}$ current, presumably owing to reactions forming $\mathrm{NiOH}$ and $\mathrm{Ni}(\mathrm{OH})_{2}$ at the catalyst surface as previously reported. In the AEMFC, however, the $\mathrm{NiCo} / \mathrm{C}$ catalysts showed two orders of magnitude lower performance with respect to the PGM-based catalysts. It is likely to be due to uneven reaction rates in the much thicker catalytic layer in the fuel cell causing severe mass transfer effects in the electrode. The use of such PGM-free catalysts in real AEMFCs 
may require higher catalysts loadings, naturally resulting in thicker catalysts layers, and hence it is important that further development in PGM-free HOR catalysts not only considers catalytic activity, but also electrode composition, morphology, as well as operating AEMFC conditions when evaluating catalysts for this application.

Supplementary Materials: The following are available online at http://www.mdpi.com/1996-1073/13/3/582/s1.

Author Contributions: Conceptualization, V.M.T., J.R.T., J.S. and M.M.; methodology, J.R.T., J.S., and M.M.; validation, V.M.T., J.R.T., J.S. and M.M.; investigation, V.M.T., J.R.T., J.S. and M.M.; resources, H.A.M., H.Y., D.R.D., S.S. and A.O.B.; data curation, A.O.B. and J.R.T.; writing—original draft preparation, A.O.B., J.R.T., M.M. and H.Y.; writing—review \& editing, A.O.B. and J.R.T.; supervision, A.O.B., S.S., H.Y. and D.R.D.; project administration, A.O.B.; funding acquisition, A.O.B., S.S., H.Y. and D.R.D. All authors have read and agreed to the published version of the manuscript.

Funding: Financial support from the Research Council of Norway, NEXTGAME project number 259554. This work was further funded by the Ministry of Science and Technology of Taiwan under the grant of MOST-105-2923-E-005-001-MY3, and supported in part by the Ministry of Education, Taiwan, R.O.C. under the Higher Education Sprout Project. Furthermore, the work was partially funded by the Nancy \& Stephan Grand Technion Energy Program (GTEP); by the European Union's Horizon 2020 research and innovation program (grant No. 721065); by the Ministry of Science, Technology \& Space of Israel through the M.Era-NET Transnational Call 2015, NEXTGAME project [grant No. 3-12940] and through grant No. 3-12948; by the Israel Science Foundation (ISF) (grant No. 1481/17); by the Ministry of National Infrastructure, Energy and Water Resources of Israel (grant No. 3-13671), by the Melvyn \& Carolyn Miller Fund for Innovation, as well as the support of Planning \& Budgeting Committee/ISRAEL Council for Higher Education (CHE) and Fuel Choice Initiative (Prime Minister Office of ISRAEL), within the framework of "Israel National Research Center for Electrochemical Propulsion (INREP).

Acknowledgments: The Norwegian Fuel Cell and Hydrogen Centre and ENERSENSE Norway is greatly acknowledged for the support. Øystein Dahl is acknowledged for assistance in collection and analysis of the XPS data.

Conflicts of Interest: The authors declare no conflicts of interest.

\section{References}

1. Varcoe, J.R.; Atanassov, P.; Dekel, D.R.; Herring, A.M.; Hickner, M.A.; Kohl, P.A.; Kucernak, A.R.; Mustain, W.E.; Nijmeijer, K.; Scott, K.; et al. Anion-exchange membranes in electrochemical energy systems. Energy Environ. Sci. 2014, 7, 3135-3191. [CrossRef]

2. Gottesfeld, S.; Dekel, D.R.; Page, M.; Bae, C.; Yan, Y.; Zelenay, P.; Kim, Y.S. Anion exchange membrane fuel cells: Current status and remaining challenges. J. Power Sources 2018, 375, 170-184. [CrossRef]

3. Burchardt, T.; Gouérec, P.; Sanchez-Cortezon, E.; Karichev, Z.; Miners, J.H. Alkaline fuel cells: Contemporary advancement and limitations. Fuel 2002, 81, 2151-2155. [CrossRef]

4. Kostowskyj, M.A.; Gilliam, R.J.; Kirk, D.W.; Thorpe, S.J. Silver nanowire catalysts for alkaline fuel cells. Int. J. Hydrogen Energy 2008, 33, 5773-5778. [CrossRef]

5. Osgood, H.; Devaguptapu, S.V.; Xu, H.; Cho, J.; Wu, G. Transition metal (Fe, $\mathrm{Co}, \mathrm{Ni}$, and Mn) oxides for oxygen reduction and evolution bifunctional catalysts in alkaline media. Nano Today 2016, 11, 601-625. [CrossRef]

6. Xin, L.; Wang, Z.; Qi, J.; Li, W. Carbon supported Ag nanoparticles as high performance cathode catalyst for $\mathrm{H}_{2} / \mathrm{O}_{2}$ anion exchange membrane fuel cell. Front. Chem. 2013, 16, 1-5. [CrossRef] [PubMed]

7. Dekel, D.R. Alkaline Membrane Fuel Cell (AMFC) Materials and System Improvement-State-of-the-Art. ECS Trans. 2013, 50, 2051-2052. [CrossRef]

8. Erikson, H.; Sarapuu, A.; Tammeveski, K. Oxygen Reduction Reaction on Silver Catalysts in Alkaline Media: A Minireview. ChemElectroChem 2019, 6, 73-86. [CrossRef]

9. Zhao, S.; Yan, L.; Luo, H.; Mustain, W.; Xu, H. Recent progress and perspectives of bifunctional oxygen reduction/evolution catatalyst development for regenerative anion exchange membrane fuel cells. Nano Energy 2018, 47, 172-198. [CrossRef]

10. Durst, J.; Siebel, A.; Simon, C.; Hasche, F.; Herranz, J.; Gasteiger, H. New insights into the electrochemical hydrogen oxidation and evolution reaction mechanism. Energy Environ. Sci. 2014, 7, 2255-2260. [CrossRef]

11. Dekel, D.R. Unraveling mysteries of hydrogen electrooxidation in anion exchange membrane fuel cells. Curr. Opin. Electrochem. 2018, 12, 182-188. [CrossRef] 
12. $\mathrm{Xu}, \mathrm{J}$; Gao, P.; Zhao, T. Non-precious $\mathrm{Co}_{3} \mathrm{O}_{4}$ nano-rod electrocatalyst for oxygen reduction reaction in anion-exchange membrane fuel cells. Energy Environ. Sci. 2012, 5, 5333-5339. [CrossRef]

13. Wang, D.-C.; Huang, N.-B.; Sun, Y.; Zhan, S.; Zhang, J.-J. GO clad $\mathrm{Co}_{3} \mathrm{O}_{4}\left(\mathrm{Co}_{3} \mathrm{O}_{4} @ \mathrm{GO}\right)$ as ORR catalyst of anion exchange membrane fuel cell. Int. J. Hydrogen Energy 2017, 42, 20216-20223. [CrossRef]

14. Liang, Y.; Li, Y.; Wang, H.; Zhou, J.; Wang, J.; Regier, T.; Dai, $\mathrm{H} . \mathrm{Co}_{3} \mathrm{O}_{4}$ nanocrystals on graphene as a synergistic catalyst for oxygen reduction reaction. Nat. Mater. 2011, 10, 780. [CrossRef] [PubMed]

15. Mamlouk, M.; Kumar, S.S.; Gouerec, P.; Scott, K. Electrochemical and fuel cell evaluation of Co based catalyst for oxygen reduction in anion exchange polymer membrane fuel cells. J. Power Sources 2011, 196, 7594-7600. [CrossRef]

16. Truong, V.M.; Wang, C.-L.; Yang, M.; Yang, H. Effect of tunable hydrophobic level in the gas diffusion substrate and microporous layer on anion exchange membrane fuel cells. J. Power Sources 2018, 402, 301-310. [CrossRef]

17. Davydova, E.S.; Mukerjee, S.; Jaouen, F.; Dekel, D.R. Electrocatalysts for hydrogen oxidation reaction in alkaline electrolytes. ACS Catal. 2018, 8, 6665-6690. [CrossRef]

18. Miller, H.A.; Lavacchi, A.; Vizza, F.; Marelli, M.; Di Benedetto, F.; D’Acapito, F.; Paska, Y.; Page, M.; Dekel, D.R. $\mathrm{A} \mathrm{Pd} / \mathrm{C}-\mathrm{CeO}_{2}$ Anode Catalyst for High-Performance Platinum-Free Anion Exchange Membrane Fuel Cells. Angew. Chem. Int. Ed. 2016, 55, 6004-6007. [CrossRef]

19. Alesker, M.; Page, M.; Shviro, M.; Paska, Y.; Gershinsky, G.; Dekel, D.R.; Zitoun, D. Palladium/nickel bifunctional electrocatalyst for hydrogen oxidation reaction in alkaline membrane fuel cell. J. Power Sources 2016, 304, 332-339. [CrossRef]

20. Dekel, D.R. Review of cell performance in anion exchange membrane fuel cells. J. Power Sources 2018, 375, 158-169. [CrossRef]

21. Omasta, T.J.; Peng, X.; Miller, H.A.; Vizza, F.; Wang, L.; Varcoe, J.R.; Dekel, D.R.; Mustain, W.E. Beyond 1.0 W $\mathrm{cm}^{-2}$ performance without platinum: The beginning of a new era in anion exchange membrane fuel cells. J. Electrochem. Soc. 2018, 165, J3039-J3044. [CrossRef]

22. Davydova, E.; Zaffran, J.; Dhaka, K.; Toroker, M.; Dekel, D. Hydrogen Oxidation on Ni-Based Electrocatalysts: The Effect of Metal Doping. Catalysts 2018, 8, 454. [CrossRef]

23. Lu, S.; Pan, J.; Huang, A.; Zhuang, L.; Lu, J. Alkaline polymer electrolyte fuel cells completely free from noble metal catalysts. Proc. Natl. Acad. Sci. USA 2008, 105, 20611-20614. [CrossRef]

24. Hu, Q.; Li, G.; Pan, J.; Tan, L.; Lu, J.; Zhuang, L. Alkaline polymer electrolyte fuel cell with Ni-based anode and Co-based cathode. Int. J. Hydrogen Energy 2013, 38, 16264-16268. [CrossRef]

25. Kabir, S.; Lemire, K.; Artyushkova, K.; Roy, A.; Odgaard, M.; Schlueter, D.; Oshchepkov, A.; Bonnefont, A.; Savinova, E.; Sabarirajan, D.C. Platinum group metal-free NiMo hydrogen oxidation catalysts: High performance and durability in alkaline exchange membrane fuel cells. J. Mater. Chem. A 2017, 5, 24433-24443. [CrossRef]

26. Roy, A.; Talarposhti, M.R.; Normile, S.J.; Zenyuk, I.V.; De Andrade, V.; Artyushkova, K.; Serov, A.; Atanassov, P. Nickel-copper supported on a carbon black hydrogen oxidation catalyst integrated into an anion-exchange membrane fuel cell. Sustain. Energy Fuels 2018, 2, 2268-2275. [CrossRef]

27. Knop, O.; Reid, K.; Sutarno; Nakagawa, Y. Chalkogenides of the transition elements. VI. X-Ray, neutron, and magnetic investigation of the spinels $\mathrm{Co}_{3} \mathrm{O}_{4}, \mathrm{NiCo}_{2} \mathrm{O}_{4}, \mathrm{Co}_{3} \mathrm{~S}_{4}$, and $\mathrm{NiCo}_{2} \mathrm{~S}_{4}$. Can. J. Chem. 1968, 46, 3463-3476. [CrossRef]

28. Ivanov, V.K.; Shcherbakov, A.B.; Usatenko, A. Structure-sensitive properties and biomedical applications of nanodispersed cerium dioxide. Russ. Chem. Rev. 2009, 78, 855. [CrossRef]

29. Paparazzo, E. On the curve-fitting of XPS Ce(3d) spectra of cerium oxides. Mater. Res. Bull. 2011, 46, 323-326. [CrossRef]

30. Burroughs, P.; Hamnett, A.; Orchard, A.F.; Thornton, G. Satellite structure in the X-ray photoelectron spectra of some binary and mixed oxides of lanthanum and cerium. J. Chem. Soc. Dalton Trans. 1976, 17, 1686-1698. [CrossRef]

31. Sharma, S.; Mukri, B.D.; Hegde, M. Direct evidence of redox interaction between metal ion and support oxide in $\mathrm{Ce}_{0.98} \mathrm{Pd}_{0.02} \mathrm{O}_{2-\delta}$ by a combined electrochemical and XPS study. Dalton Trans. 2011, 40, 11480-11489. [CrossRef] [PubMed]

32. Brun, M.; Berthet, A.; Bertolini, J. XPS, AES and Auger parameter of Pd and PdO. J. Electron Spectrosc. Relat. Phenom. 1999, 104, 55-60. [CrossRef] 
33. Shafeev, G.; Themlin, J.M.; Bellard, L.; Marine, W.; Cros, A. Enhanced adherence of area-selective electroless metal plating on insulators. J. Vac. Sci. Technol. A Vac. Surf. Film. 1996, 14, 319-326. [CrossRef]

34. Kim, K.S.; Gossmann, A.; Winograd, N. X-ray photoelectron spectroscopic studies of palladium oxides and the palladium-oxygen electrode. Anal. Chem. 1974, 46, 197-200. [CrossRef]

35. Li, L.; Zhang, N.; He, H.; Zhang, G.; Song, L.; Qiu, W. Shape-controlled synthesis of Pd nanocrystals with exposed $\{110\}$ facets and their catalytic applications. Catal. Today 2019, 327, 28-36. [CrossRef]

36. Priolkar, K.; Bera, P.; Sarode, P.; Hegde, M.; Emura, S.; Kumashiro, R.; Lalla, N. Formation of $\mathrm{Ce}_{1-x} \mathrm{Pd}_{\mathrm{x}} \mathrm{O}_{2-\delta}$ Solid Solution in Combustion-Synthesized $\mathrm{Pd} / \mathrm{CeO}_{2}$ Catalyst: XRD, XPS, and EXAFS Investigation. Chem. Mater. 2002, 14, 2120-2128. [CrossRef]

37. Mason, M.; Gerenser, L.; Lee, S.-T. Electronic structure of catalytic metal clusters studied by X-ray photoemission spectroscopy. Phys. Rev. Lett. 1977, 39, 288. [CrossRef]

38. Zhou, W.P.; Lewera, A.; Larsen, R.; Masel, R.I.; Bagus, P.S.; Wieckowski, A. Size effects in electronic and catalytic properties of unsupported palladium nanoparticles in electrooxidation of formic acid. J. Phys. Chem. B 2006, 110, 13393-13398. [CrossRef]

39. Nishizawa, T.; Ishida, K. The Co-Ni (Cobalt-Nickel) system. Bull. Alloy Phase Diagr. 1983, 4, $390-395$. [CrossRef]

40. Houska, C.R.; Averbach, B.L.; Cohen, M. The cobalt transformation. Acta Metall. 1960, 8, 81-87. [CrossRef]

41. Kitakami, O.; Sato, H.; Shimada, Y.; Sato, F.; Tanaka, M. Size Effect on the Crystal Phase of Cobalt Fine. Phys. Rev. B 1997, 56, 13849. [CrossRef]

42. Moreau, L.M.; Ha, D.-H.; Bealing, C.R.; Zhang, H.; Hennig, R.G.; Robinson, R.D. Unintended phosphorus doping of nickel nanoparticles during synthesis with TOP: A discovery through structural analysis. Nano Lett. 2012, 12, 4530-4539. [CrossRef] [PubMed]

43. Grosvenor, A.P.; Biesinger, M.C.; Smart, R.S.C.; McIntyre, N.S. New interpretations of XPS spectra of nickel metal and oxides. Surf. Sci. 2006, 600, 1771-1779. [CrossRef]

44. Roberts, M.W.; Smart, R.S.C. The defect structure of nickel oxide surfaces as revealed by photoelectron spectroscopy. J. Chem. Soc. Faraday Trans. 1 Phys. Chem. Condens. Phases 1984, 80, 2957-2968. [CrossRef]

45. Carley, A.; Jackson, S.; O'shea, J.; Roberts, M. The formation and characterisation of Ni3+-an X-ray photoelectron spectroscopic investigation of potassium-doped Ni (110)-O. Surf. Sci. 1999, 440, L868-L874. [CrossRef]

46. Li-Shing, H.; Williams, R.S. Electronic-structure study of the Ni Ga and the Ni In intermetallic compounds using X-ray photoemission spectroscopy. J. Phys. Chem. Solids 1994, 55, 305-312. [CrossRef]

47. McIntyre, N.; Cook, M. X-ray photoelectron studies on some oxides and hydroxides of cobalt, nickel, and copper. Anal. Chem. 1975, 47, 2208-2213. [CrossRef]

48. Schenck, C.; Dillard, J.; Murray, J. Surface analysis and the adsorption of Co (II) on goethite. J. Colloid Interface Sci. 1983, 95, 398-409. [CrossRef]

49. Chuang, T.; Brundle, C.; Rice, D. Interpretation of the x-ray photoemission spectra of cobalt oxides and cobalt oxide surfaces. Surf. Sci. 1976, 59, 413-429. [CrossRef]

50. Chen, R.; Yang, C.; Cai, W.; Wang, H.-Y.; Miao, J.; Zhang, L.; Chen, S.; Liu, B. Use of Platinum as the Counter Electrode to Study the Activity of Nonprecious Metal Catalysts for the Hydrogen Evolution Reaction. ACS Energy Lett. 2017, 2, 1070-1075. [CrossRef]

51. Chen, J.G.; Jones, C.W.; Linic, S.; Stamenkovic, V.R. Best Practices in Pursuit of Topics in Heterogeneous Electrocatalysis. ACS Catal. 2017, 7, 6392-6393. [CrossRef]

52. Campos-Roldán, C.; González-Huerta, R.; Alonso-Vante, N. Experimental protocol for HOR and ORR in alkaline electrochemical measurements. J. Electrochem. Soc. 2018, 165, J3001-J3007. [CrossRef]

53. Davydova, E.S.; Speck, F.D.; Paul, M.T.Y.; Dekel, D.R.; Cherevko, S. Stability Limits of Ni-Based Hydrogen Oxidation Electrocatalysts for Anion Exchange Membrane Fuel Cells. ACS Catal. 2019, 9, 6837-6845. [CrossRef]

54. Alsabet, M.; Grden, M.; Jerkiewicz, G. Electrochemical growth of surface oxides on nickel. Part 1: Formation of $\alpha-\mathrm{Ni}(\mathrm{OH})_{2}$ in relation to the polarization potential, polarization time, and temperature. Electrocatalysis 2011, 2, 317-330. [CrossRef]

55. Alsabet, M.; Grdeń, M.; Jerkiewicz, G. Electrochemical growth of surface oxides on nickel. Part 3: Formation of $\beta-\mathrm{NiOOH}$ in relation to the polarization potential, polarization time, and temperature. Electrocatalysis 2015, 6, 60-71. [CrossRef] 
56. Darab, M.; Barnett, A.O.; Lindbergh, G.; Thomassen, M.S.; Sunde, S. The influence of catalyst layer thickness on the performance and degradation of PEM fuel cell cathodes with constant catalyst loading. Electrochim. Acta 2017, 232, 505-516. [CrossRef]

57. Liu, Z.-Q.; Xu, Q.-Z.; Wang, J.-Y.; Li, N.; Guo, S.-H.; Su, Y.-Z.; Wang, H.-J.; Zhang, J.-H.; Chen, S. Facile hydrothermal synthesis of urchin-like $\mathrm{NiCO}_{2} \mathrm{O}_{4}$ spheres as efficient electrocatalysts for oxygen reduction reaction. Int. J. Hydrogen. Energy 2013, 38, 6657-6662. [CrossRef]

58. Carenco, S.; Boissiere, C.; Nicole, L.; Sanchez, C.; Le Floch, P.; Mézailles, N. Controlled design of size-tunable monodisperse nickel nanoparticles. Chem. Mater. 2010, 22, 1340-1349. [CrossRef]

59. Pan, J.; Chen, C.; Li, Y.; Wang, L.; Tan, L.; Li, G.; Tang, X.; Xiao, L.; Lu, J.; Zhuang, L. Constructing ionic highway in alkaline polymer electrolytes. Energy Environ. Sci. 2014, 7, 354-360. [CrossRef]

60. Lindström, R.W.; Kortsdottir, K.; Wesselmark, M.; Oyarce, A.; Lagergren, C.; Lindbergh, G. Active Area Determination of Porous Pt Electrodes Used in Polymer Electrolyte Fuel Cells: Temperature and Humidity Effects. J. Electrochem. Soc. 2010, 157, B1795-B1801. [CrossRef]

(C) 2020 by the authors. Licensee MDPI, Basel, Switzerland. This article is an open access article distributed under the terms and conditions of the Creative Commons Attribution (CC BY) license (http://creativecommons.org/licenses/by/4.0/). 